

\section{DISCLAIMER}

This document was prepared as an account of work sponsored by an agency of the United States Government. Neither the United States Government nor the University of California nor any of their employees, makes any warranty, express or implied, of assumes any legal liability or responsibility for the accuracy, completeness, or usefulness of any information, apparatus, product, or process disclosed, or represents that its use would not infringe privately owned rights. Reference herein to any specific commercial products, process, or service by trade name, trademark, manufacturer, or otherwise, does not necessarily constitute or imply its endorsement, recommendation, or favoring by the United States Government or the University of California. The views and opinions of authors expressed herein do not necessarily state or reflect those of the United States Government thereof, and shall not be used for advertising or product endorsement purposes.

Work performed under the auspices of the U.S. Department of Energy by Lawrence Livermore National Laboratory under Contract W-7405-Eng-48. 
UCRL-53196

Distribution Category UC-66

\title{
Direct Use of Hydrothermal Energy: Review of Environmental Aspects
}

\author{
K. O'Banion \\ D. Layton
}

August 28, 1981

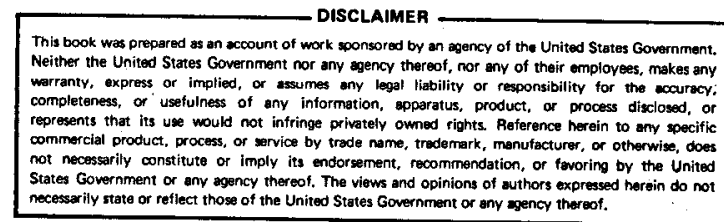

LAWRENCE LIVERMORE LABORATORY

University of California $\bullet$ Livermore, California $\bullet 94550$

Available from: National Technical Information Service U.S. Department of Commerce \$285 Port Royal Road $\bullet$ Springfield, VA $22161 \bullet \$ 6.00$ per copy $\bullet$ (Microfiche \$3.50) 
This document reviews and evaluates the potential environmental impacts of the exploration, development and production of hydrothermal geothermal energy for direct use applications. Production of electricity is not included in this review.

The document is intended to provide a current, independent and objective assessment of the risks and potential impacts of this technology by:

(1) identifying major current environmental and safety concerns;

(2) identifying mitigation strategies; and (3) pointing out research and development needs where appropriate.

This document is one of several assessments of energy technologies prepared for DOE management and persons having interest and responsibility in this area.

Robert Blaunstein, Manager

Solar, Geothermal and Conservation Programs

Technology Assessments Division 
TABLE OF CONTENTS

I. Introduction

II. Hydrothermal Energy

Page

$\begin{array}{ll}\text { Advantages } & 6 \\ \text { Disadvantages } & 6\end{array}$

$\begin{array}{ll}\text { Advantages } & 6 \\ \text { Disadvantages } & 6\end{array}$

III. Technology of Direct Use 10

Production 10

Utilization 12

Fluid Disposal 13

IV. Direct Use Applications $\quad 18$

Space Conditioning $\quad 18$

Agricultural and Industrial Uses 21

v. Potential Environmental Impacts: Exploration, Field 24

Development, Production and Reinjection (by phase)

General Construction 25

Casual Use $\quad 28$

Pre-lease Exploration $\quad 28$

Post-lease Exploration 29

Field Development and Production 34

Abandonment and Restoration 39

VI. Summary of Impacts and Mitigation: Exploration, Field 39

Development, Production, and Reinjection (by type of impact)

Landscape Disturbance $\quad 39$

Noise and Human Activity $\quad 43$

Water Contamination 43

Land Subsidence $\quad 44$

Surface Flow Reduction 45

Induced Seismicity 45

VII. Potential Environmental Impacts: Utilization 45

VIII. Conclusions 47

IX. References $\quad 48$ 
DIRECT USE OF GEOTHERMAL ENERGY:

REVIEW OF ENVIRONMENTAL ASPECTS

\section{ABSTRACT}

This report is generic look at the potential environmental impacts of direct use of hydrothermal energy, and is intended to serve both as a guide for policymakers and as an aid to project-specific environmental analyses. It is not a substitute for those analyses, of course, since hydrothermal resources occur in a wide variety of environments, and can be utilized in a wide variety of ways. The production of hydrothermal energy for direct use poses a wide range of potential impacts. However, all are largely or entirely avoidable, by careful siting and timing; by established mitigation techniques; by reinjecting spent fluid; and by adequately restoring the vacated field. In areas of special ecological or recreational value, disturbance of the landscape can be further reduced by utilizing multiwell drillpads and by burying fluid lines. Direct-use applications are so numerous and diverse that the impacts cannot be done justice in a generic report, except to note that the sparsely developed and relatively stable regions in which hydrothermal resources tend to be found are far more vulnerable to socioeconomic disruption than are more urbanized regions. 
$-$

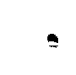

$\bullet$ 


\section{INTRODUCTION}

The United States today produces only about $75 \%$ of the energy it consumes. The $\$ 30 \mathrm{billion/year}$ we spend on Imported petroleum to make up the balance is both a drain on our economy and a risk to national security. While the deregulation of ofl and natural gas prices may be expected to stimulate new exploration, the U.S. will be fortunate if the results are enough to keep domestic oil and gas production at their present levels. Enterpreneurs have searched the continental U.S. for so long ( $120 \mathrm{yr})$ that a large, sustainable increase in production is unlikely. The other "conventional" alternatives, coal and nuclear fission, are both embroiled in controversy over their external costs which, particularly in the latter case, have placed any near-term contribution to the U.S. energy budget in serious jeopardy (Stobaugh and Yergin, 1979).

Among the "unconventional" domestic sources of energy, hydrothermal energy may be the closest to being economical on a large scale. Hydrothemal energy Is geothermal energy in the form of hot water and steam that occurs naturally at many locations beneath the earth's surface. It can be utilized either to generate electricity (at temperatures $>150^{\circ} \mathrm{C}$ ) or as direct heat in space conditioning and other uses. The U.S. Department of Energy (DOE) has a number of programs to encourage the use of hydrothermal geothermal energy for both electric generation and direct use. As a result, it also has the obligation under law to assess the potential environmental impacts of the increased use of this energy form. 


\section{HYDROTHERMAL ENERGY}

Hot or molten rock lying relatively close to the earth's surface is the ultimate heat source for most hydrothermal energy resources suitable for direct use. The heat is transferred to water contained in overlying porous or fractured rock. Above the permeable rock is a layer of impermeable rock confining the superheated water. If this layer is extensively fractured, however, the fluid escapes at the surface as either steam or hot water. Two types of hydrothermal convection systems are recognized: vapor-dominated resources (dry steam) and 1 iquid-dominated resources (hot water). Few vapor-dominated resources are known to exist because of the unique geologic conditions they require. Only three have been identified in the U.S.: The Geysers, near Clear Lake, CA; the Mud Volcano system in Yellowstone National Park, WY; and Mt. Lassen National Park, CA. Only The Geysers resource has been developed for hydrothermal production.

In general, the geologic conditions that cause hydrothermal convection are associated with tectonic plate boundaries and volcanic activity, and in the U.S. are confined almost entirely to the portion west of the 105th meridian (Fig. 1, Table 1). The U.S. Geological Survey (USGS) estimates the domestic resource base, for discovered hydrothermal systems $>90^{\circ} \mathrm{C}$, to be $(1650 \pm 140) \times$ $10^{18} \mathrm{~J}$, of which $(400 \pm 60) \times 10^{18} \mathrm{~J}$ is recoverable at the surface

(Table 2). However, because generation of electric power is now feasible only at a fluid temperature $>150^{\circ} \mathrm{C}$, almost half this amount can be utilized only as direct heat. US S estimates the "beneficial", or end-use, heat value of the sub- $150^{\circ}$ resource to be $(42 \pm 13) \times 10^{18} \mathrm{~J}$ (Brook et al., 1979).

This last figure is equivalent to the energy content of $(6.9 \pm 2.1) \times 10^{9}$ bbl of oil, or from 1.5 to almost 3 years' worth of oil imports. Moreover, this figure includes only discovered hydrothermal systems at depths of $<3 \mathrm{~km}$. USGS estimates the beneficial heat value of the undiscovered resource at $<3 \mathrm{~km}$ to be 4-7 times that of the discovered resource; and any future technological improvements or economic developments that extend this depth 1 imitation will increase the resource base still further (Brook et al. 1979).

The use of hydrothermal energy as direct heat poses both advantages and disadvantages in comparison with alternative fuels: 


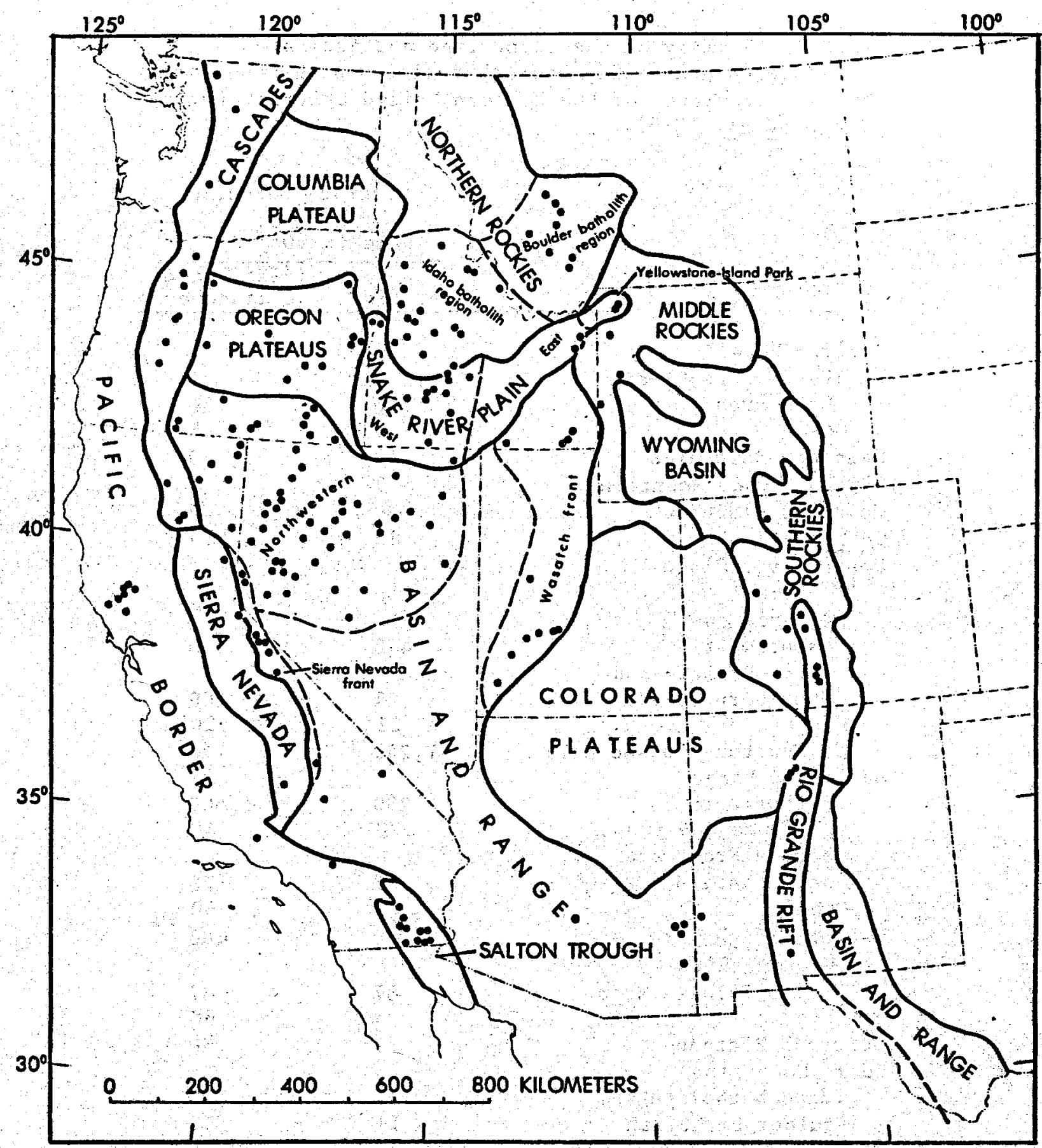

Figure 1. Geologic provinces of the western U.S. Dots indicate locations of identified hydrothermal convection systems (Brook et al., 1979). 
Table 1. Sumary of the identified and estimated undiscovered accessible hydrothermal resource base for geologic provinces of the Western United States (Fig. 1) (Brook et al. 1979).

\begin{tabular}{cc} 
Accessible resource \\
Province & $\begin{array}{c}\text { base }\left(\times 10^{18} \mathrm{~J}\right) \\
\text { Identified Undiscovered }\end{array}$ \\
\hline
\end{tabular}

Pacific Border

The Geysers-Clear

Identified

Undiscovered

Lake area

Other

Cascades Mountains

Sierra Nevada Mountains

Columbia Plateau

Oregon Plateaus

Snake River Plain

Western

Central and

southwest

Camas Prairie and northern margin

Eastern

Yellowstone-Island Park

Basin and Range

Northwestern

Sierra Nevada front

Wasatch Front and

northeastern margin

Other

Salton Trough

Rio Grande rift

Valles Caldera area

Other

Colorado Plateaus

Rocky Mountains

Idaho batholith

Boulder batholith

Middle Rocky Mountains

and Wyoming Basin

Southern Rocky Mountains

Alaska

Alaska Peninsula and

Aleutian Islands

150

15

3

0

80

470

940

21

21

1,240

280

120

67

12

240

87

6

1

100

1,520

170

1,400

40

14

11

170

60

480

Central Alaska

Southeast Alaska

Hawai i
15

5

0

400 
TABLE 2. Summary of energies of hydrothermal convection systems $>90^{\circ} \mathrm{C}$ (Brook et al., 1979). (Not included in this table is the accessible resource base in National Parks, estimates as $\overline{1290} \times 10^{18} \mathrm{~J}$.)

\begin{tabular}{|c|c|c|c|c|c|}
\hline a & $\begin{array}{l}\text { Number of } \\
\text { systems }\end{array}$ & $\begin{array}{c}\text { Accessible } \\
\text { resource base } \\
\left(10^{18} \mathrm{~J}\right)\end{array}$ & $\begin{array}{l}\text { Resource } \\
\left(10^{18} \mathrm{~J}\right)\end{array}$ & $\begin{array}{c}\text { Electrical } \\
\text { energy } \\
\left(\mathrm{MW}_{\mathrm{e}} \text { for } 30 \mathrm{yr}\right)\end{array}$ & $\begin{array}{c}\text { Beneficial } \\
\text { heat } \\
\left(10^{18} \mathrm{~J}\right)\end{array}$ \\
\hline $\begin{array}{l}\text { IDENTIFIED (excluding } \\
\text { National Parks) }\end{array}$ & & $\because$ & 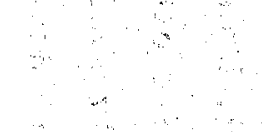 & & \\
\hline $\begin{array}{l}\text { Vapor-dominated (The } \\
\text { Geysers) }\end{array}$ & 1 & $100 \pm 24$ & $9.3 \pm 4.5$ & $1630 \pm 770$ & -- \\
\hline Hot-water $>150^{\circ} \mathrm{C}$ & 51 & $850 \pm 80$ & $210 \pm 30$ & $21000 \pm 3300$ & -- \\
\hline Hot-water $90^{\circ}-150^{\circ} \mathrm{C}$ & 163 & $700 \pm 110$ & $176 \pm 55$ & -- & $42 \pm 13$ \\
\hline Total identified & $\overline{215}$ & $\overline{1650 \pm 140}$ & $\overline{400 \pm 60}$ & $23,000 \pm 3400$ & $42 \pm 13$ \\
\hline UNDISCOVERED & & & & & \\
\hline $\begin{array}{l}\text { Vapor-dominated and } \\
\text { hot-water }>150^{\circ} \mathrm{C}\end{array}$ & - & $2800-4900$ & $700-1230$ & $72,000-127,000$ & \\
\hline Hot-water $90^{\circ}-150^{\circ} \mathrm{C}$ & - & $5200-3100$ & $1300-770$ & -- & $184-310$ \\
\hline Total undiscovered & -- & 8000 & 2000 & $72,000-127,000$ & $184-310$ \\
\hline $\begin{array}{l}\text { TOTAL identified (exclu } \\
\text { National Parks) and } \\
\text { undiscovered }\end{array}$ & & 9600 & 2400 & $95,000-150,000$ & $230-350$ \\
\hline
\end{tabular}




\section{ADVANTAGES}

Known technology. The technology of producing and directly using hydrothermal energy is known, and has been demonstrated on a large scale in several countries, notably the Soviet Union, Hungary, and Iceland. The equipment and methods required for fluid production are very similar to those used in oil and gas production, and utilization does not differ in any fundamental way from the utilization of any other form of hot water. While some advances are required for lower-grade resources to become feasible (e.g., prevention of corrosion, reductions in drilling cost), they are incremental rather than revolutionary in nature (National Research Council, 1979).

Reliability and continuous availability. Each reservoir has its own recharge capacity, and withdrawals beyond the rate at which fluid is replaced and heated can cause a gradual decline in the obtainable flow of energy. As long as withdrawals are kept at or below this rate, however, hydrotherma 1 convection is a renewable source of energy. Moreover, unlike other renewable sources, such as wind or solar radiation, it is continuously available.

Predictable cost. A powerful incentive for end-users to develop their own hydrothermal systems is that, except for the fraction spent on operating and maintaining the system, the cost of energy is limited to the amortization of capital outlay(s). Thus, whereas energy tends in the normal case to be one of the most unpredictable variables in business planning, with hydrothermal systems it becomes an almost fixed cost. This is desirable in any case, but particularly so for private firms in which energy cost is a major component of price.

Short leadtime. Many other forms of energy have extraordinarily long leadtimes, due in large part to the need for large-scale intermediate facilities (e.g., refineries for oil, gasifiers/liquifiers for coal synfuels, turbine plants for electricity). Direct use of hydrothermal energy does not require such facilities, and thus can be developed in comparatively short order.

\section{DISADVANTAGES}

Resource uncertainty. Despite the efforts of USGS, DOE and others, substantial uncertainty exists as to the production rates, 1 ifetimes, and locations of individual reservoirs. While the credibility of reservoir 
assessments is improving, any longterm commitment to hydrothermal energy entails a heavy risk in all but the largest and most extensively explored resource areas, partly from the lack of resource knowledge and partly from the fact that present surface surveying techniques are not well enough developed to ensure a high probability that a drill hole will intercept a resource. Hydrothermal reservoirs are never uniform or continuous, and unproductive holes are sometimes drilled in the middle of the best of resources.

Present developers of electrical power generation from high-temperature reservoirs are generally large resource companies that can finance reservoir confirmation by spreading the high risk and cost over many projects. However, most of these large companies are not interested in development or utilization of lower-temperature reservoirs because of the relatively non-intensive scale of such projects (King et al., 1980). Smaller developers, the ones most likely to be interested in low- and moderate temperature geothermal resources, are often unable to spread risk and cost in the same way that a large company can. DOE now has programs to indemnify producers (the User Coupled Confirmation Program) against the risks of exploration and lenders (the Geothermal Loan Guarantee Program) against loan default, but no programs now exist to indemnify the end-user against depletion of the resource.

Low profit margin. Related to the question of uncertainty is the low profitability of a hydrothermal well compared to an oil or natural gas well. These ventures are similar not only in the equipment and methods used, but also in the respect that potential profit has to be large in order to compensate for the substantial risk they entail. Unfortunately, given an oil well and a hydrothermal well of comparable cost, if the oil well yields 500 $\mathrm{bbl} / \mathrm{d}$ and the hydrothermal we $1150 \mathrm{l} / \mathrm{s}$ at a $\Delta_{t}$ of $33^{\circ} \mathrm{C}$, the earnings from the former would be up to an order of magnitude greater (Kunze et al., 1979). In order to compete for financing, then, the risk for hydrothermal energy has to be significantly lower; this is not yet the case.

Isolation of resource areas. The distribution of hydrothermal resources could hardly be more inconvenient. In general, discovered resources are located in some of the most sparsely developed areas of the U.S., remote from potential users. The largest cost component in multiuser direct heat systems tends to be the distribution network; for example, distribution has comprised over $60 \%$ of the cost of the district heat system in Reykjavik, Iceland (Einarsson, 1975). Thus, hydrothermal heat is most economical when demand is 
concentrated, i.e. in dense residential areas and/or at one or more large industrial users. Unfortunately, towns in the mountain and basin West tend to be widely spaced, developed at a very low density, and have negligible industry.

A number of large cities do overlie hypothesized $10 \mathrm{w}$-temperature $\left(<90^{\circ} \mathrm{C}\right)$ reservoirs: Phoenix, Las Vegas, Tucson, Salt Lake City, E1 Paso, Reno, and Boise. However, except for the two known hydrothermal systems just south of Reno, reservoirs $>90^{\circ} \mathrm{C}$ are remote from any sizeable concentrations of population. In order for hydrothermal direct use to make a significant contribution to the U.S. energy budget, then, either prospective users must move to the resource or the resource must be transported to the users.

Certainly, long-distance pipelines for hydrothermal fluid are technologically feasible; fluids $>150^{\circ} \mathrm{C}$ can be transported $160 \mathrm{~km}$ in buried, insulated pipe with a loss of only a few degrees ${ }^{\circ} \mathrm{C}$ (Basse, 1976). Whether it is also economically feasible depends on the distance it has to be transported; the amount of pumping required by the intervening terrain; and the cost of easements. An inherent drawback of long-distance transport, however, is that the fluid would have to be returned to the producing reservoir in order to be reinjected, increasing capital cost even further. But if the spent fluid is not returned to the producing reservoir, 1) some alternative means of disposal must be found; 2) if withdrawals exceed the recharge rate, the flow obtainable from the reservoir would be depleted over time; and 3) the likelihood of land subsidence would be increased. Moreover, while a transport radius of, say, $160 \mathrm{~km}$ would expand the potential market for hydrothermal direct heat tremendously (it would, for example, bring the San Francisco Bay area within reach of the Geysers-Clear Lake systems and most of Oregon's population within reach of systems in the (ascade Range), in most cases large terrain differentials lie between resource and market areas. Any such changes in elevation can produce huge increases in the cost of pump power as a fraction of total $\mathrm{MW}_{t}$ delivered (Fig. 2) (Basse, 1976).

Fluid corrosivity. Hydrothermal fluids contain a variety of gases and minerals that can corrode or cause scaling in system components. The chemical species found in fluids are a function of reservoir geology, but those listed in Table 3 are found to some extent in all fluids (Lienau et al, 1979). 

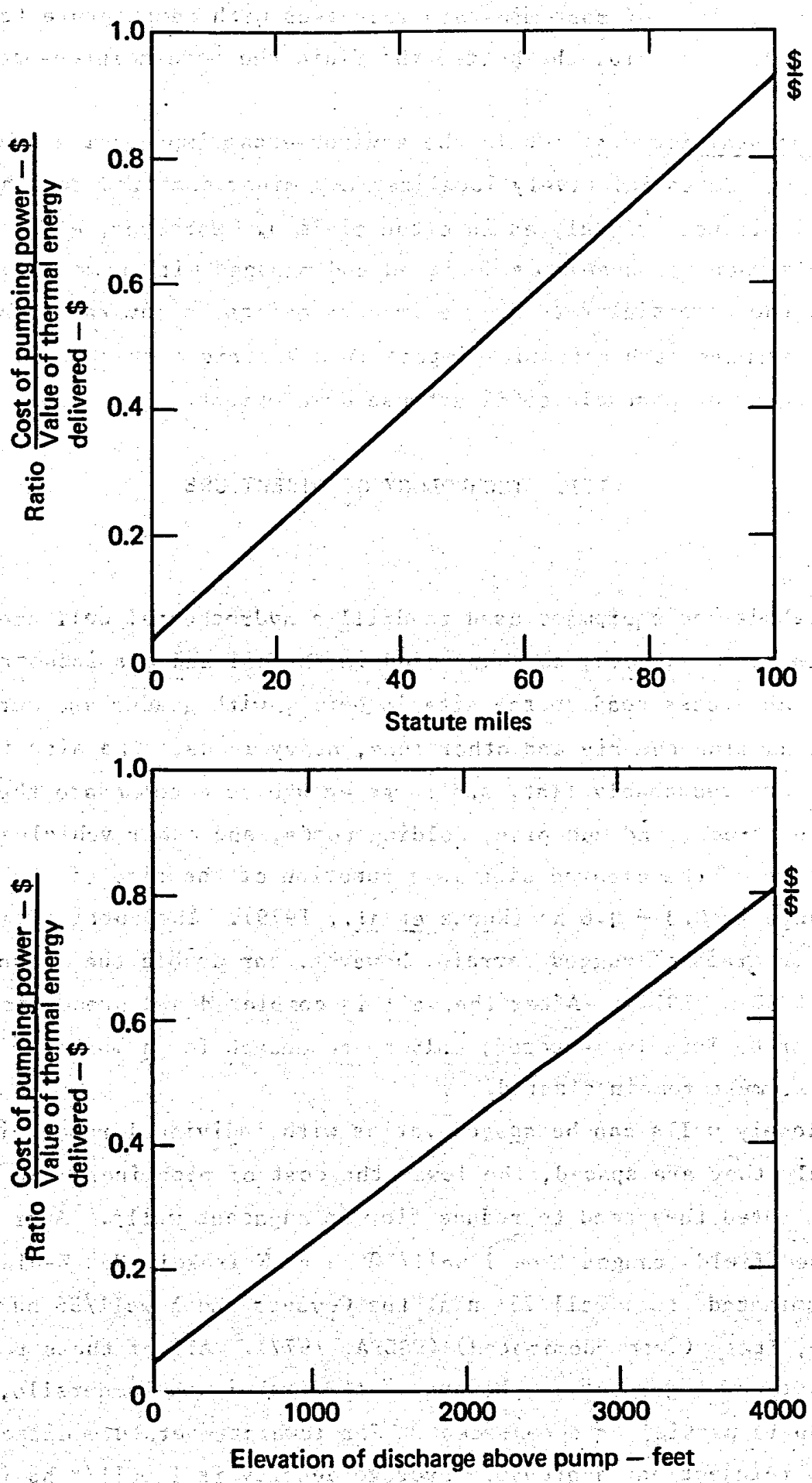

Figure 2. Ratio of pumping cost to energy value in level pipe (top) and from lower to higher elevations (bottom). Basis: 12 in pipe, $140^{\circ} \mathrm{C}$ fluid (Basse, 1976). 
Since the solubility of most minerals increases with temperature (calcite is an exception), in general the hotter the fluid the more maintenance the system requires.

Environmental impacts. While the environmental impact of a hydrothermal direct-use system is relatively localized and minor compared to other energy systems', it is not trivial, as is often claimed. Moreover, even the former is true only when the system is designed and managed with utmost care;

otherwise, the potential for adverse impacts exists in several areas. In this report, we examine each potential impact in a generic context, and assess its significance as an obstacle to direct-use development.

\section{TECHNOLOGY OF DIRECT USE}

\section{PRODUCTION}

The methods and equipment used to drill a hydrothermal well are very similar, in most respects, to those used in the oil and gas industry (Fig. 3). An access road to the site is built, with grades and curves gentle enough for hauling the rig and other long, heavy loads. The site itself must be cleared and reasonably flat, and large enough to accomodate the drill rig, an equipment truck, and mud pits, holding ponds, and other vehicles. The required size of the cleared site is a function of the size of the rig; a typical range is $0.3-0.8$ ha (Kunze et $1 ., 1979$ ). The cutting and filling necessary in areas of rugged terrain, however, can double the amount of land disturbed (USEPA, 1977). After the well is completed and production begins, the site can be largely restored; only space enough for a workover rig, for repair work, must remain cleared.

How closely wells can be spaced varies with individual reservoirs. The more closely they are spaced, the lower the cost of pipelines; but if they are too concentrated they tend to reduce flow in adjacent wells. Average density at developed fields ranges from 1 well/10 ha at Wairakei, New Zealand (1iquid-dominated) to 1 well/23 ha at the Geysers and 1 well/36 ha at Lardare110, Italy (vapor-dominated) (USEPA, 1977). Al1 of these resources are utilized for power generation, however, at Wairakei and Larderello, reinjection is partial or nonexistent. For lower-temperature direct use, and with total reinjection, a probable average density is 1 well/8 ha (Basse, 1976). 


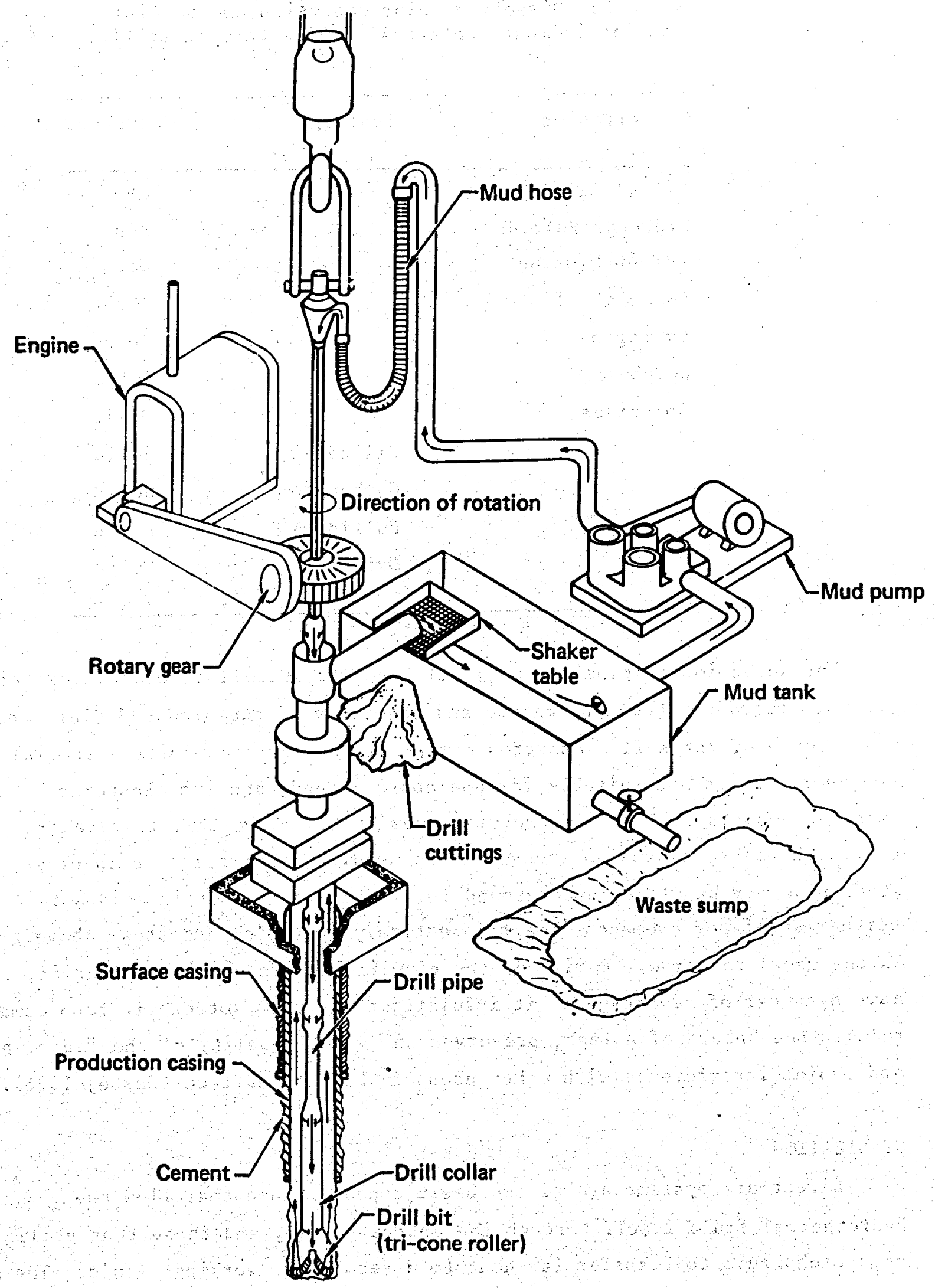

Figure 3. Typical rotary drilling equipment (Kunze et al., 1979). 
Table 3. Dissolved major corrosion and scaling species in most geothermal fluids (Lienau et al., 1979).

\begin{tabular}{lcc}
\hline \multicolumn{1}{|c}{ Corrosion } & Scaling & Character \\
\hline Oxygen (in leakage) & & Gas \\
Hydrogen Sulfide & & Gas \\
Carbon Dioxide & Gas \\
Ammonia & Gas \\
Hydrogen & & Ions \\
Sulphates & & Solid \\
Chlorides & & Solid \\
& & Solid \\
& Silicates & Solid \\
& Carbonates & Solid \\
& Sulfides & Solid \\
\hline
\end{tabular}

The selection of pipeline material, and its installation above or below ground, depends on the temperature and chemistry of the produced fluid and on the acidity of the soil. Asbestos cement is the most economical material, but in general it is not suitable for use above ground, and its elastomer expansion joints fail at temperatures over $99^{\circ} \mathrm{C}$. Above this temperature stee 1 pipe with welded expansion loops must be used. With protective coatings, steel pipe may be placed underground in alkaline soil, but in acid soil neither steel nor asbestos cement is entirely suitable, and steel above ground is the usual recourse. Burial of the pipeline, where conditions permit, does have number of advantages: it insulates the line, protects it from damage, reduces the hazard of a leak, preserves the visual quality of the landscape, and avoids interference with other uses of the land surface (Basse, 1976).

\section{UTILIZATION}

Direct-use systems are of two basic types: those that flow the hydrothermal fluid itself through the entire system, and those that utilize heat exchangers to transfer its heat to a secondary "working" fluid. The main 
reason for heat exchanger is to isolate the hydrothermal fluid, with its impurities, to a few system components that can be easily cleaned or replaced, and to confine the use of more expensive corrosion-resistant materials to those components. Since the temperature of the hydrothermal fluid is decreased in the system, solids tend to precipitate out as scale. If the scale forms on a heat-transfer surface, such as the inside of a heater coil, resistance to transfer is increased and output is lowered. Also, as scale buildup continues, flow becomes restricted. With a secondary fluid, scale buildup is localized in the heat exchanger itself, and a standby exchanger can be incorporated into the system so that maintenance of the normal exchanger does not force a shutdown (Lienau et al., 1979). Heat exchangers may also be categorized into two basic types: surface and downhole.

Downhole heat exchanger. This type consists of one or two tube loops suspended in the well, in direct contact with the hydrothermal fluid. Clean water is circulated through the loops to pick up heat. Downhole exchangers have several advantages: front-end cost is the lowest of all types; in most instances the secondary water cycles thermally, so a pump is not required; and the problem of disposal of hydrothermal fluid is eliminated (Balzhiser, 1980). On the other hand, downole exchangers are feasible only where reservoir depth is $<150 \mathrm{~m}$ (up to $450 \mathrm{~m}$ under certain conditions) (Lienau et al., 1979). Most of the 400 wells in Klamath Falls, OR utilize downole exchangers (Lund et al., 1974).

Surface heat exchangers. Of the various types of surface exchangers available, the plate type exchanger seems to be the most suitable for hydrothermal systems. Unlike downhole exchangers, al1 types of surface exchangers require extraction of fluid from the reservoir, and thus also require reinjection or some other means of disposal.

\section{FLUID DISPOSAL}

Systems using hydrothermal fluid directly or in surface heat exchangers must dispose of the spent fluid in a way both environmentally responsible and economically feasible.

Surface disposal. The former practice of simply dumping untreated spent fluid into the nearest watercourse is now either outlawed or restricted to 
circumstances where the fluid is of exceptional quality and its volume is low compared to the flow in the watercourse. Regional Water Quality Control Boards in California, for example, do not now permit discharge to surface water in any case. In Oregon, surface disposal may not be considered except in the rare instance when reinjection is not practicable for geophysical (not merely economic) reasons. Idaho and Nevada consider requests on a case-by-case basis; there is no general ban on surface disposal, but the chemical and/or thermal characteristics of spent fluid often preclude it unless the fluid is treated beforehand.

The present California ban on surface disposal undoubtedly reflects the fact most of its hydrothermal experience has been with superhot steam and fluid (i.e., The Geysers, Imperial Valley), which have far greater concentrations of impurities than do lower-temperature fluids; it is thus conceivable this ban may be relaxed if interest in direct use grows. On the other hand, all state water criteria are subject to periodic review and with each review the criteria become more inclusive and more restrictive. Thus, while about half of the direct use projects supported under the DOE Loan Guarantee Program, to date have obtained surface discharge permits, this percentage is likely to decline in the future, particularly as more and larger projects come before the permit boards.

Table 4 presents geochemical data on four different sample thermal waters from the western U.S., which vary a great deal in their composition and potential toxicity. The thermal water from the Boise area, for example, is almost of drinking water quality, except for the elevated level of fluoride; in order to discharge this fluid to surface water, the fluoride would have to be reduced by treatment. The concentrations of arsenic in the waters from Steambiat Hot Springs and Amedee Hot Springs both exceed the federal drinking water standard for that element $(0.05 \mathrm{ppm})$; again, treatment would be required before surface disposal (see below).

In the other surface alternative, ponding, fluid is ultimately disposed of by leaching and/or evaporation. Ponds are viable only if potable groundwaters are isolated from the leachate and only in areas where the evaporation rate is high enough, year-round, to handle the large volumes of spent fluid. Thus, while ponding is the best (cheapest) alternative for short-term operations such as well testing, the geologic and climatic requirements for its long-term use could prove to be quite restrictive. 
Table 4. Chemistry of selected thermal waters (USGS, 1980).

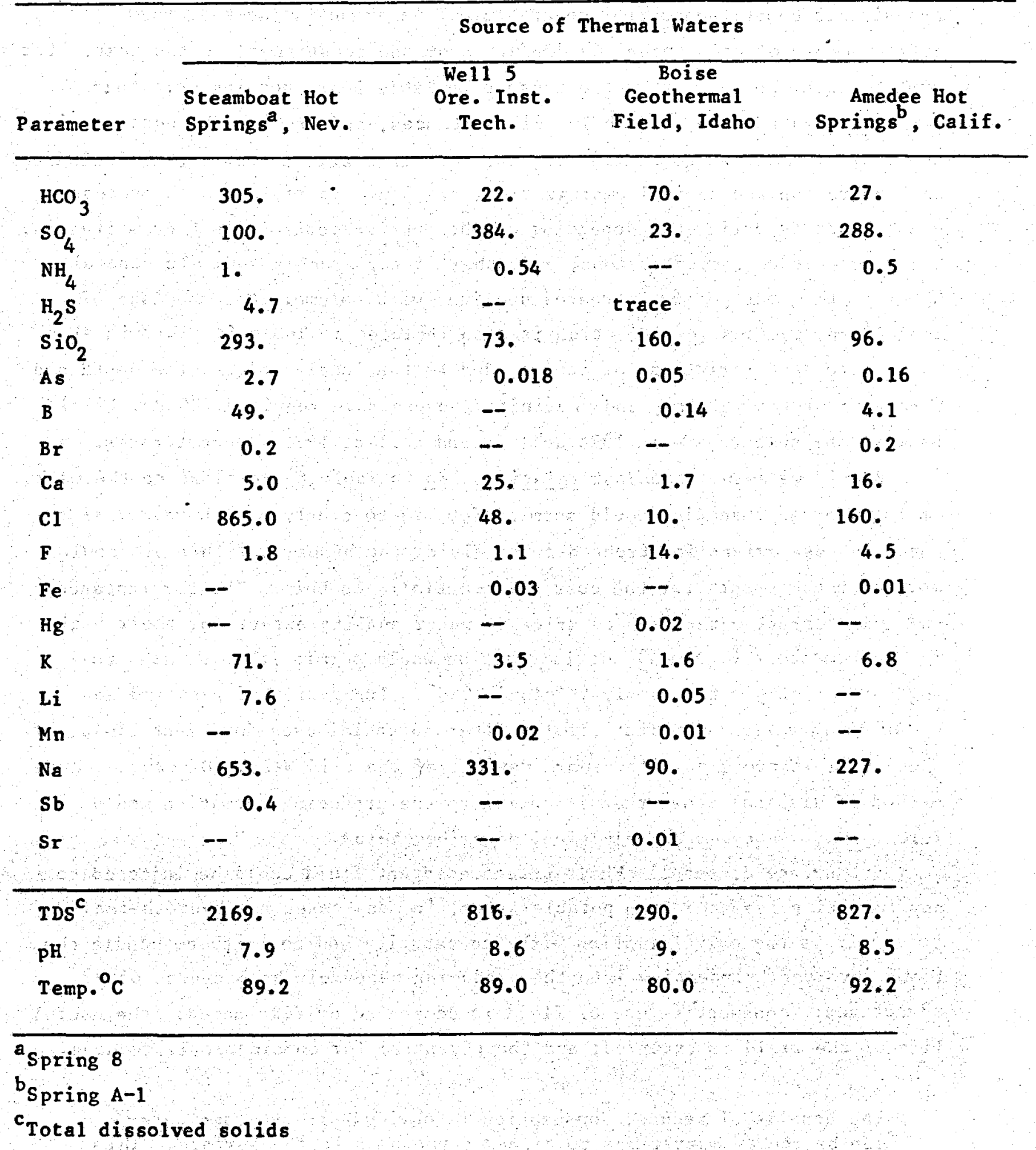


Treatment of spent fluid. A variety of techniques exist for removing undesirable constituents from spent fluid. As shown in Table 5 , the effectiveriess of each technique differs from one constituent to the next. (It must be said, however, that the numbers in Table 5 are nothing more than reported results under particular circumstances, and are not the outcome of any comprehensive assessment.) The costs of the various techniques, including both operation and capital amortization, are shown in Table 6 . These costs are subject to variation, depending on the combinations of fluid constituents, their respective concentrations, and other factors such as $\mathrm{pH}$. In general, however, the cost per unit treated declines with volume. For the sake of comparison, the cost of injection is also included in Table 6. This is also subject to some variation, of course, due to the local geology, the depth and bore size of the well(s), and the injection pressure required (USEPA, 1978). Lastly, the numbers are in 1975 dollars and reflect 1975 interest rates.

But if we assume the cost relationships in Table 6 are close to the mark, on the average injection would seem preferable to treatment. However, if a potential use exists for treated spent fluid, the benefit of this use could more than compensate for the cost differential. In Boise, ID, for instance, the hydrothermal waters are of drinking-water quality except for their high fluoride content (Table 4); defluoridation would permit it to be used to augment the city water supply (Rigdon, 1980). Irrigation of farmland and creation of wetlands habitat are two other potential uses for spent fluid, of particular interest to water-short regions of the arid West. Of course, any method of disposal other than injection to the producing formation would forego the advantages of injection, described below.

Subsurface disposal. While untreated spent fluid could be injected to any formation isolated from potable water, in many cases the hydrothermal reservoir is the only formation with the capacity and porosity to handle the flows involved. Injecting into the producing reservoir has several other advantages: consumptive use of fluid is decreased or eliminated; the useful life of the field is extended; and the potential for subsidence is reduced.

The benefit of reduced consumption is obvious, as the same water can be reused many times to transfer the heat to the surface. This method can extend the useful life of the field through conservation of both the water and the thermal energy. Under nearly all reservoir 
conditions, there is more heat stored in the rocks in the reservoir than in the water, so recycling the water extracts more heat from the rocks.

The 1 ife of the reservoir can also be extended by returning the energy-laden water to the reservoir . . in practice, most (systems) utilize only $10-25 \%$ of the hest contained in the water and reject the rest. If this heat normally rejected were returned to the reservoir, less total heat would be required over the life of the field. There is a serious concern that the returned geothermal fluid might cool the reservoir. In most cases, a change in temperature of a few degrees does not significantly affect a space- or process-heating use and the benefit of extending the life of the field makes injection a good trade of

(Kunze et al., 1979).

Subsurface injection may also require some treatment of the spent fluid, but limited in general to removal of suspended solids, which could plug the wellbore.

Table 5. Reported efficiencies of wastewater treatment methods (USEPA, 1978 ).

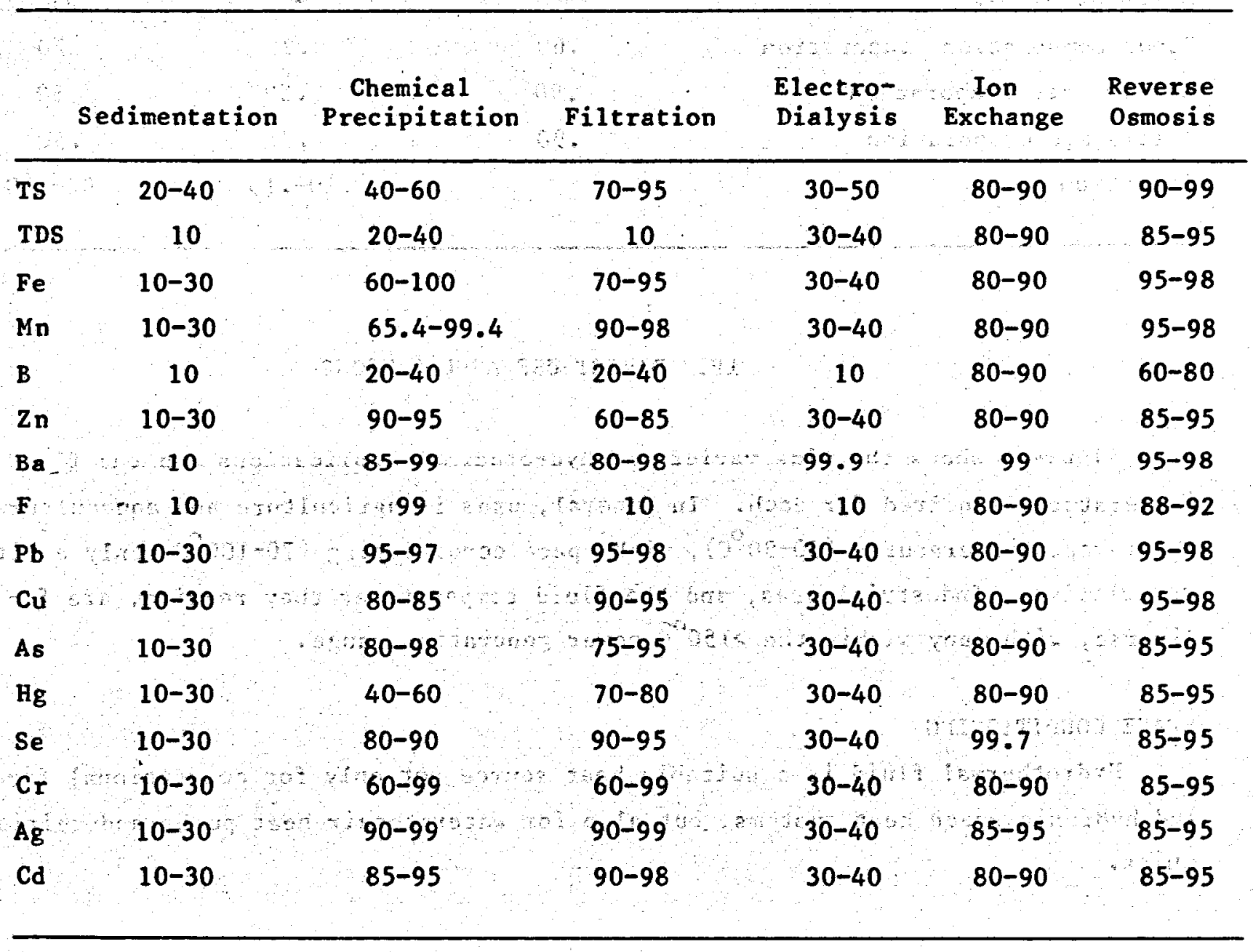


Table 6. Costs of wastewater treatment methods (USEPA, 1978).

$\begin{array}{cccc} & \$ / 1000 \text { liters } & \$ / 10001 \text { iters } & \$ / 10001 \text { iters } \\ \text { Process } & 0101 \mathrm{pm} & 010001 \mathrm{pm} & \$ 100,0001 \mathrm{pm}\end{array}$

Sedimentation

1-stage lime addition

2-stage lime addition

Alum addition

Ferric chloride addition

Filtration

Ion exchange

Reverse Osmosis

Electrodialysis

Vapor compression evaporation

Multieffect evaporation

Multistage evaporation

Injection
2.50

4.50

6.00

4.50

6.00

1.10

.30

.30

$--$

.60

.90

.90
.22

.42

.59

.54

.63

.25

.16

.28

$--$

.25

.59

.71

$.10-.15$
.01

.02

.01

.06

.07

.06

.09

.12

.30

.20

.50

.50

$.02-.10$

\section{DIRECT USE APPLICATIONS}

Figure 4 shows the wide variety of hydrothermal applications and the fluid temperatures required for each. In general, uses in agriculture and aquaculture permit the lowest temperatures $\left(30-90^{\circ} \mathrm{C}\right)$, with space conditioning $\left(70-100^{\circ} \mathrm{C}\right)$ on $1 \mathrm{y}$ a bit more restrictive. Industrial uses, and the fluid temperatures they require, are far more diverse, with many within the $>150^{\circ} \mathrm{C}$ power generation range.

\section{SPACE CONDITIONING}

Hydrothermal fluid is a suitable heat source not only for conventional forced air and hydronic space heat systems, but also for water-to-air heat pumps and refrigerationunits. 


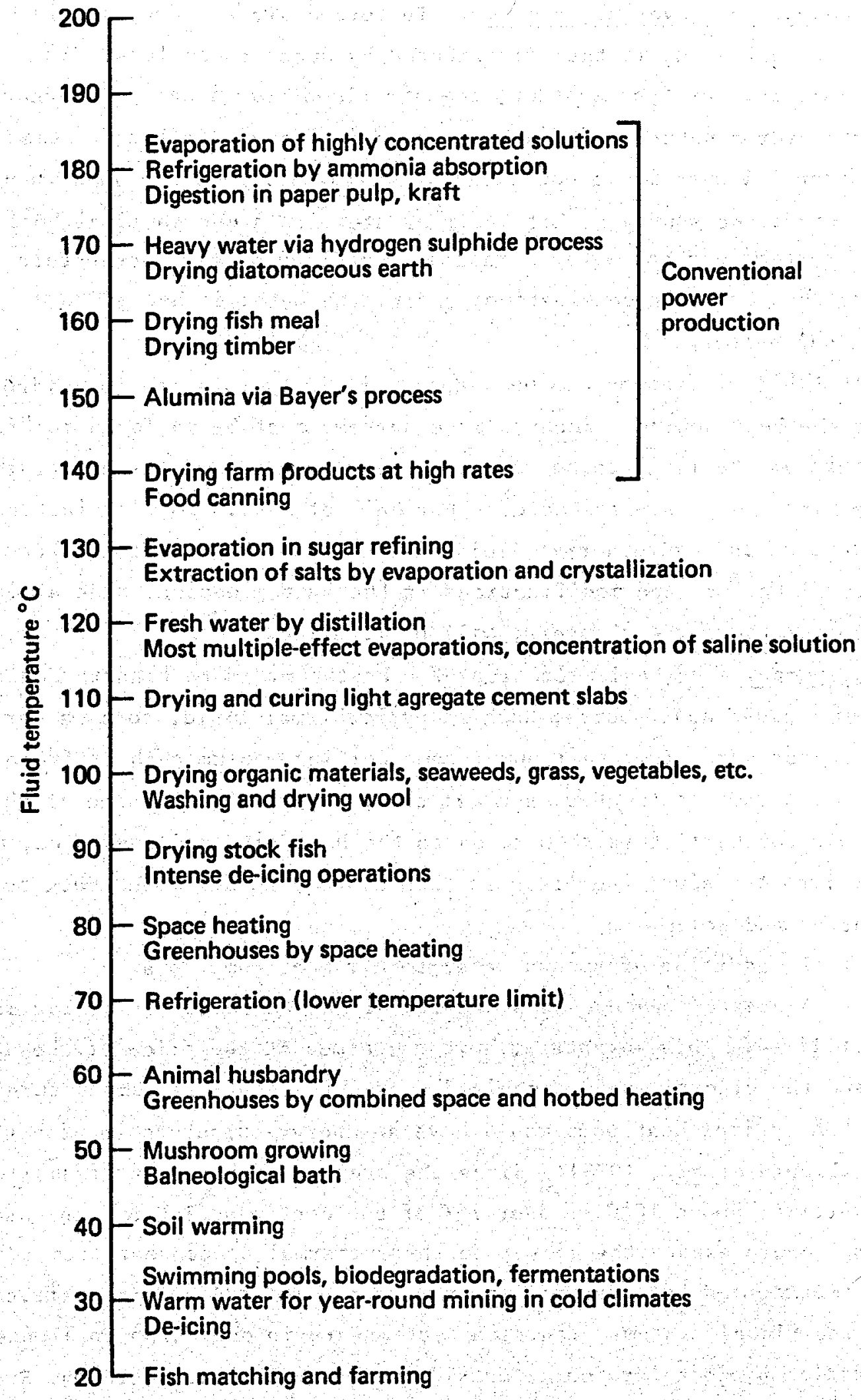

Figure 4. Fluid temperatures required for various direct use applications (Lienau et al., 1979). 
Forced-air and hydronic systems. In forced air systems, air is blown over a heat source and is then distributed by ducts to outlets. In residential, furnace type systems, the air flows over a heat exchanger positioned over a natural gas; oil, or propane flame. In larger commercial or multiresidential systems, a hot water or steam coil is often used in place of the exchanger; the source of hot water or steam is a conventional boiler. Hydronic systems use hot water directly in radiant panels, convectors and radiators, singly or in combination; again, the water is heated in a conventional boiler.

Both types of systems can be adapted simply by substituting hydrothermal fluid as the heat source. However, the systems must be tailored to "fit" the temperature of the fluid to be used, in order to maximize the heat extracted perpass, and thus minimize the cost per unit of heat. In most instances, the temperature of the hydrothermal fluid will be lower than that produced by a conventional boiler, and modifications in the system design, such as increased surface area for heat exchangers, will be required.

Heat pumps. The basic function of a heat pump is to transfer energy from a low-temperature heat source, such as hydrothermal fluid, to a warmer medium such as indoor air. In a heat pump, some working medium such as freon is exposed, as a gas, to the heat source; the cool gas absorbs some of the heat and expands further; it is then moved to the heat sink and condensed, driving off heat into the sink; the freon is then evaporated and moved back to the heat source; and so on.

With the addition of such a water-to air heat pump to a hydrothermal-adapted space heat system, fluid at temperatures as low as $10^{\circ} \mathrm{C}$ can be utilized. This advantage, however, comes at the price of the pump itself and the electric power required to run it; at fluid temperatures of $15-30^{\circ} \mathrm{C}$ the typical heat pump would have an energy output-to input ratio of about 3 (Lienau et al, 1979). Since the average temperature of shallow ground water is above $10^{\circ} \mathrm{C}$ in over $75 \%$ of the continental U.S., the use of heat pumps could expand the market for hydrothermal space heat tremendously. Heat-pump-augmented hydrothermal space heat can be utilized in district as well as individual systems; ten such systems are in operation in France, and demonstration projects are under consideration in Denmark, Germany, Sweden, Austria, Switzerland and the Netherlands (Lienau, 1980). 
Refrigeration. The two presently available systems that are adaptable to hydrothermal energy are the ammonia-water and the water-1ithium-bromide cycles. The water-lithium-bromide is the more popular of the two because it is simpler, performs better, and does not have the disadvantage of using ammonia, a mildly toxic, combustible substance. - It also can utilize lower fluid temperatures, as $10 \mathrm{w}$ as $110^{\circ} \mathrm{C}$ compared to $150^{\circ} \mathrm{C}$ or over for ammonia-water systems. However, since the working fluid of the water-1ithium-bromide system is water, it cannot produce temperatures below $0^{\circ} \mathrm{C}$. Ammonia-water units can produce temperatures down to about $-40^{\circ} \mathrm{C}$; but due to the hazardous nature of ammonia, such units are limited to applications where there is consistent monitoring of the system, or where the total amount of ammonia is small enough not to pose a problem (e.g.', in home refrigerators) (Reistad, 1975).

Recently, a third type of adaptable system has been developed. This system is similar in concept to an electric heat pump, but the motor and compressor are replaced by a hydrothermal-driven vapor-jet compressor, based on the principle that a jet of fluid creats a partial vacuum that can be used as a pump. The main advantage of the vapor-jet system is that it can be driven by fluids as low as $60^{\circ} \mathrm{C}$. However, at its present stage the system has a low efficiency, and due to the design concept cannot be made in large-capacity sizes (Haven et al , 1980).

\section{AGRICULTURAL AND INDUSTRIAL USES}

Hydrothermal energy can be utilized in a wide variety of agricultural and industrial applications. Many of those require fluid temperatures $>150^{\circ} \mathrm{C}$ (Fig. 4), however, and we expect power generation to dominate those resources for some time to come. The remainder may be categorized as relating either to agricultural growing, or to agricultural or industrial processing, The growing-related category includes:

\section{greenhousing,}

mushroom culturing,

livestock raising,

- soil warming, aquaculture, and

biogas production. 
The basic operations in the processing-related category are :

- preheating,

- washing,

- cooking and peeling;

- evaporating,

- sterilizing,

- distilling and separating,

- drying, and

- refrigeration.

We expect that most, by far, of the energy contribution hydrothermal direct use will make in this century will be in space conditioning (including its use in the agricultural sector for greenhousing, mushroom culturing, and livestock raising) for several reasons:

- The larger a percentage the cost of energy contributes to total production cost, the greater the incentive to pursue energy savings by conversion to hydrothermal direct heat. Whereas energy cost tends to be a minor $(<10 \%)$ component of total cost in industrial operations, in the case of space heat provided by a utility system the percentage can range up to $50 \%$ (Howard, 1975).

- Of the heating energy used in the U.S. in the range of $50-149^{\circ} \mathrm{C}$, space heat comprises $62 \%$ (Fig. 5). Industrial uses (other than space heat), on the other hand, comprise only 17\%. Clearly, a large shift in the former to hydrothermal energy would have a significant impact on the U.S. energy picture, while a shift of the same proportional size in the industrial sector would not.

- Industrial and agricultural processing are more constrained in terms of location than space conditioning and, to a lesser extent, agricultural growing. For the former, the prime locational considerations tend to be availability of raw material (first) and quality of transportation (second) (Bressler and Hanemann, $1980 \mathrm{a}, \mathrm{b}, \mathrm{c}$ ). In order for hydrothermal direct use to be feasible; those factors would have to coincide with a hydrothermal resource at the proper temperature. On the other hand, space conditioning is feasible at any hydrothermal resource area as long as some demand, from any source, exists for residential and sales/service development. Agricultural growing is more constrained than space conditioning, but less so than processing; while it does not require raw materials, it does require proximity to market areas, as well as a suitable climate (Bressler and Hanemann, 1980d). 


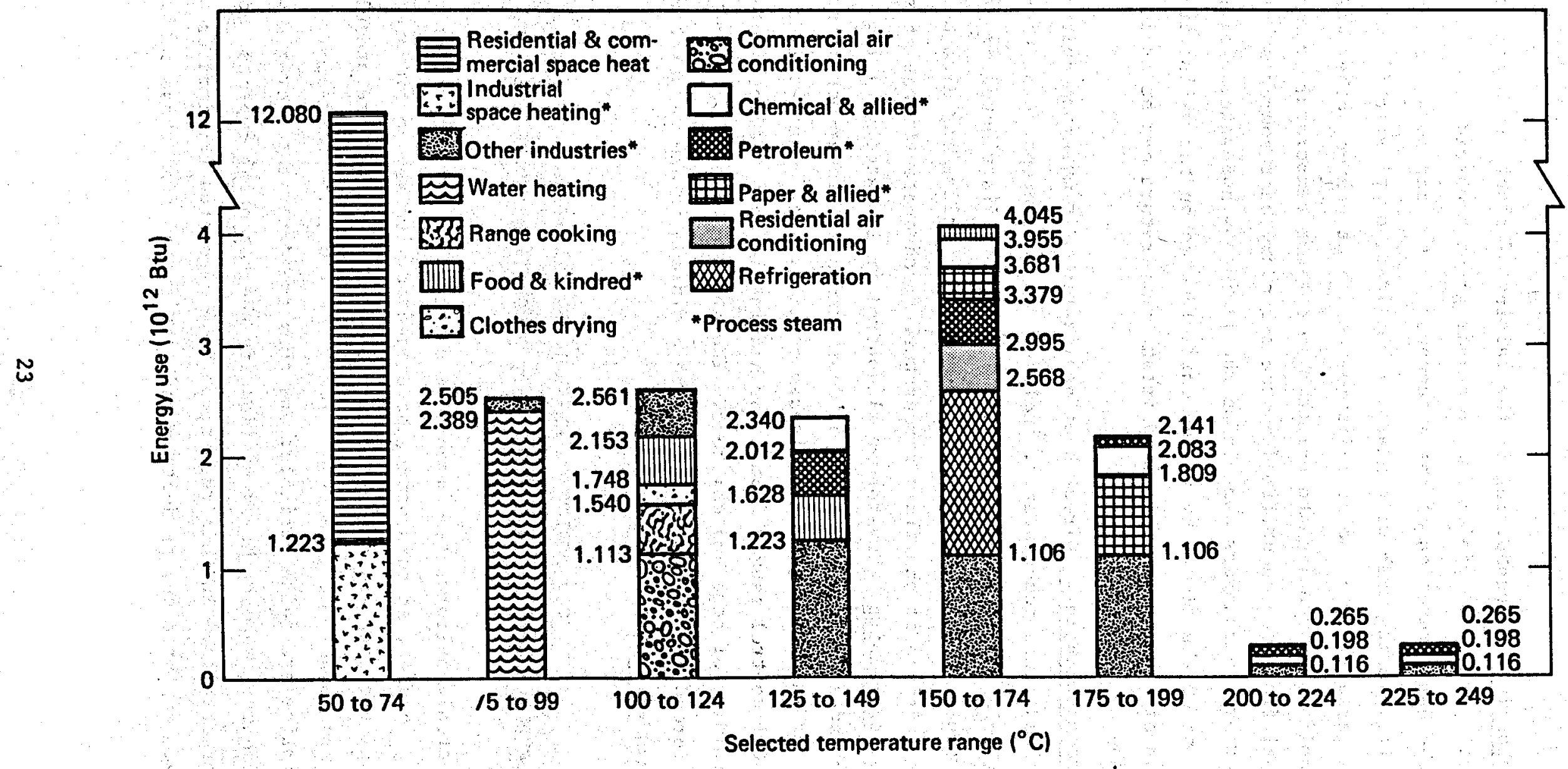

Figure 5. Use of heating energy in the U.S. by sector and output temperature (Reistad, 1975). 
Greenhousing. Greenhousing is the raising of plants in a controlled environment, to improve yields and to permit growing outside normal seasonal limits. The basic function of the greenhouse is to trap solar heat by enclosing the growing area with glass, fiberglass, or plastic film. However, due to the variability of solar radiation as a heat source, other means of heating/cooling are required to maintain an optimum temperature range. Hydrothermal fluid can be utilized as the secondary heat source by circulation of air over heat exchangers containing the fluid; by hot-water piping or ducts located in or on the floor; by finned units located on the walls; or by a combination of the above. The fluid intake temperature can be as low as $32^{\circ} \mathrm{C}$ (Lienau et al., 1979).

Mushroom culturing. Direct heat applications in mushroom culturing, and their required fluid temperatures, include: compost preparation $\left(54-60^{\circ} \mathrm{C}\right)$, spawning $\left(22-24^{\circ} \mathrm{C}\right)$, and production $\left(26^{\circ} \mathrm{C}\right)$. Heat is distributed by exposed hot water pipes along the mushroom-house walls. Cooling may also be hydrothermal-driven if the fluid temperature is adequate (Lienau et al., 1979). Livestock raising. Environmental control in livestock raising provides significant advantages compared to outdoor exposure: lower mortality, faster growth, lower fat levels, easier disease control, etc. The level of environmental control ranges from floor heating in open feedlots to completely enclosed raising of hogs and chickens. The enclosed systems use both radiant panel and forced air heating, and require a minimum intake temperature of $32^{\circ} \mathrm{C}$ (Lienau et al.; 1979).

\section{POTENTIAL ENVIRONMENTAL IMPACTS:}

EXPLORATION, FIELD DEVELOPMENT, PRODUCTION AND REINJECTION

The actual environmental impacts of direct heat development in the western U.S. cannot, at this point, be projected with any confidence: estimates of the size and energy content of most resources are speculative, based on very scanty data; their physical, chemical, and thermal characteristics are quite variable; and they are distributed over a wide range of enviromments. We can, however, identify the potential impacts such development entails. In this report, we have separated the impacts of field development, exploration, production and reinjection from those activities 
related to utilization. We do so because the former are essentially the same regardless of the end use, and thus their potential impacts can be anticipated with relative certainty. Note, however, that use of downhole heat exchangers would obviate those impacts associated with fluid withdrawal and reinjection. End uses, by contrast, are so diverse, and influenced by so many factors other than those related to energy, that it is extremely hard to make generalizations that are both useful and valid; accordingly, our treatment of utilization's potential impacts is 1 imited.

Since hydrothermal development is in fact a sequence of phases, its potential impacts are first described in the context of that sequence:

- Casual use

- Pre-lease exploration

- Post-lease exploration

- Field development and production

- Abandonment and restoration

We also include one activity, general construction, that occurs in every phase except casual use. Following the phase-by-phase identification of potential impacts, the impacts are summarized by type, and mitigation measures described.

GENERAL CONSTRUCTION

General construction includes roads, pads, and mud sumps; foundations for structures and pipelines; and parking lots and storage areas. The tasks involved are devegetation, rough grading, cutting and filling, soil compaction, final grading, and maintenance.

Employment. Site preparation, requiring a crew of up to ten equipment operators and laborers per "field", is contracted out to a local firm; other local contractors may be hired to repair equipment, landscape the site, etc. Whether or not the demand for construction labor can be met within a given regional market depends on the pace of development as well as the size of the market, but unlike well drilling (see POST-LEASE EXPLORATION below), the skills required in general construction are common ones available in almost any locality. While all but the most sparsely populated markets should be able to provide the labor required for a single field, the scheduling of a number of projects within a region could lead to some inmigration if construction timeframes overlap and/or if the pace of development is expected to continue to increase (Haven et al., 1980). 
Landscape disturbance. Alteration of natural contours and removal of vegetation combine to increase the susceptibility of soil to erosion; this is particularly serious in mountainous areas, not only because runoff velocity is greater, but also because such areas require much more cutting and filling in order to provide level roads and pads. Erosion impacts both land ecosystems, by removing topsoil, and aquatic ecosystems, by increasing sediment and nutrient loads. Suspended sediment interferes with fish respiration and obstructs penetration of light into water, hindering the ability of fish to locate prey and reducing photosynthesis in aquatic vegetation. Sediment may invade spawning areas, discouraging reproduction, and may be deposited at the mouths of streams and rivers, altering flow. An increase in soil nutrients in the water body can lead to eutrophication and subsequent oxygen depletion. Alteration of natural contours can also induce landslides in areas of steep terrain and unstable bedrock. As well as the damage they cause directly, landslides also change surface and subsurface drainage, particularly if slide material dams up watercourses, and increases soil erosion.

On land, changes in nutrient cycles may result from increased aeration, exposure of subsurface soils to evaporation, and temperature changes having adverse impacts on microflora and fauna. Some reptiles and burrowing mammals are lost directly as a result of construction activity; others disperse into the surrounding habitat where they are subject to predation or starvation due to overpopulation. In general, carnivores and raptors are less vulnerable to localized disturbances, since they range over wider areas, but may lose their young if the disturbance occurs close to nesting sites (Woodward-clyde, 1978). Linear features such as roads can fragment the habitats into isolated segments which themselves may not be viable. Small animals may be reluctant to cross the roads and thus expose themselves to predators; and larger shy animals may avoid the roads altogether if they are frequented by humans.

Because the subsurface soils exposed by clearing and grading, erosion, and landslides are in general coarsely textured and low in nutritive value, construction can permanently impair the ability of the land to sustain the vegetation mix that previously existed. Moreover, even if vegetation can restore itself over the long term, in most instances it must go through successional stages, each with its own unique mix of plant abundance and diversity. Alterations of the physical structure and of nutrient cycles of 
the habitat can in turn lead to shifts in faunal populations. Some species may benefit, for example by the increase in ecotonal area due to replanting devegetated land with grasses, while others may be lost due to the removal of cover (USFWS, 1976).

Disturbance of the landscape can also damage its visual quality. In hilly terrain, the scars created by cutting and filling for roads, pads and sumps can be visible for miles, as can the cleared firebreaks for surface pipelines. This is an especial problem when the landscape has recreational value: not only do its users lose a source of pleasure, but if the local economy is tourism oriented, the income of residents can decline significantly. The Clear Lake basin in The eysers region is one example of such a conflict (O'Banion and Hall, 1980).

Because only a low percentage of land within a hydrothermal field must be disturbed, it is generally possible to avoid known historic or archaeologic resources even when they are located within the field. Grading and excavation may, however, disclose resources not previously known. This is a particularly significant problem for hydrothermal tesources, since hot springs were often important to Native Americans for religious and/or functional reasons, and thus artifacts tend to be more predominant in such areas.

Air emissions. The use of heavy equipment produces both exhaust fumes and dust. Dust is produced by movement of vehicles on unsurfaced roads and by wind on cleared land, as well as by earth movement itself. Dust can inhibit vegetation growth and, at sites very close to water, can increase its sediment load; except under abnormal conditions such as a drought, however, dust extends no more than $20-25$ m from its source (USFWS, 1976).

The diese 1 engines that run heavy equipment emit so, No $x^{2} \mathrm{Co}$, unburned hydrocarbons and particulates; but the quantities are insignificant. For example, two pieces of equipment working for 5 days and using $500 \mathrm{gal}$ of fuel in building one pad would emit $13.51 \mathrm{~b} \mathrm{so}, 1851 \mathrm{~b}$ No, $112.51 \mathrm{~b}$ CO, $18.51 \mathrm{~b}$ hydrocarbons, and $6.5 \mathrm{lb}$ particulates.

Noise. Road building equipment emits noise in the range of $80-90 \mathrm{dBA}$ at $15 \mathrm{~m}$, which attenuates $6 \mathrm{dBA}$ with each doubling of distance from the source. The impact of noise on wildlife behavior is not well understood, although it is likely to be adverse for species who rely largely on sound for hunting, mating, or defense. Animals are also likely to be more sensitive to noise and human intrusion at certain points in their life cycles: nesting or mating, for 
example (Nielson et al., 1975). On the other hand, there is ample evidence many species can become conditioned to quite loud noises when they are sustained or repeated over a long period of time (Goodwin, 1975). How objectionable the noise is to humans in the vicinity is a function of the background noise level and the type of activity they are engaged in; however, at least in recreational and quiet residential areas the noise produced by construction would significantly detract from their use. (See also the discussion of drilling noise under POST-LEASE EXPLORATION.)

\section{CASUAL USE}

The casual use phase of hydrothermal development includes aerial photo and infrared surveying, rock and water sampling, and geologic mapping. Impacts in this phase are confined to those caused by transport of field crews and gear in light vehicles and, if lodging is not available nearby, by the crew camp. The impacts of both should be transitory and insignificant, as long as vehicles are restricted to roads and trails and responsible camp practices are followed. Off-road use of vehicles, however, can result in localized damage: it disturbs topsoil and thus interferes with nutrient cycling; destroys vegetation; compacts the soil; creates ruts which accelerate runoff and thus soil erosion; causes sedimentation in crossing streams; and introduces noise to otherwise quiet environs.

\section{PRE-LEASE EXPLORATION}

If the initial results are encouraging, the developer proceeds to more intensive exploration, consisting of various geophysical surveys and the drilling of shallow $(<150 \mathrm{~m})$ temperature gradient wells. The impacts of transporting and housing are similar to those described under CASUAL USE, except more off-road vehicular travel may be required.

The impacts of temperature gradient wells are insignificant, as a rule. Generally, limited site preparation is necessary, and noise and dust produced are also limited, since only a small truck-mounted drill rig is required. A certain amount of soil compaction and plant destruction results from rig placement, and $0.8-1.6 \mathrm{~m}^{3}$ of drill cuttings, too low in fertility to sustain vegetation, are normally left in a pile onsite. Other potential impacts include spillage of fuel and lubricants; noise and site disturbance due to human and vehicular activity; and increased soil erosion on the disturbed portion of the site. Given the scale of this operation, all should be minor. 


\section{POST-LEASE EXPLORATION}

After lease purchase, the developer drills 1-5 deep wells for locating and testing hydrothermal fluids.

Employment. Drilling is generally contracted out by the developer to a rig operator, who employs a nucleus of regular employees who travel with the rig wherever it goes. Each rig is operated $24 \mathrm{hr} / \mathrm{d}$ for $40-60 \mathrm{~d}$, and requires 21-25 workers, divided into four crews of 5-6 people each and a rig supervisor. In The Geysers region, where quite intensive development is expected to continue for many years, a skilled labor pool of some 250-300 drillers live in the region (although the individuals in the pool change constantly, as some rigs are moved outside the region and others are moved in). But since direct use development is expected to be far less intensive, it is very unlikely that similar pools would develop in response to it. Particularly since the deregulation of oil and gas prices, rigs are in great demand, and even if future jobs are anticipated in an area, the operators can not afford any slack time. Thus, most if not all rig personnel will be imported for the job and depart once it is complete. Given the size of the crew, the relatively short duration of their stay in the area, and the fact that very few crewmen have families traveling with them, their impact on the local economy, services, and cultural fabric should be insignificant (Haven et a1., 1980).

If a town with accommodations is nearby, the crew is housed there, but in remote areas accommodations must be provided onsite, in house trailers, campers and/or tents. A site for the trailers/tents must be cleared and leveled, but due to the scale and limited duration of the camp, in general its potential impacts are minor, as long as construction and sanitation are responsibly managed.

\section{Site preparation}

To drill deep wells requires heavy equipment such as cement trucks, rig structures, etc, and thus roads must be built both from the nearest existing road to the area of exploration, and between each of the wellpads (if more than one): A cleared, leveled, compacted pad of about 0.8 ha is required for the rig and other equipment to be set up. Each exploratory well requires its own pad; however, in the production phase, several deviated wells can be drilled from a single, but larger pad, albeit at greater cost. A sump must 
be constructed next to each pad for the temporary storage of cuttings, drilling muds and hydrothermal fluid produced during short tests. Due to the toxicity of some mud and fluid constituents (see Table 4), the sump must be impervious, lined with clay, plastic, or cement. If the wastes in the sump are not toxic, they may be evaporated and graded over; toxic wastes, however, must be transported to a licensed disposal site (USEPA, 1977; Morris and Layton, 1980). (Potential impacts related to road, pad, and sump construction are covered in GENERAL CONSTRUCTION.)

\section{Deep well drilling}

Heavy-duty oil rigs are used, powered by diesel electric generators, and run $24 \mathrm{hr} / \mathrm{d}$. Drilling muds lubricate the bit, cool the formation, transport cuttings to the surface, seal the walls of the hole, and prevent blowouts; the mud is discharged into a sump (previous section), where it cools and particulates settle out, and then is recirculated and reused.

Blowouts. Well blowouts can occur in several ways; steam may escape through weak rock below the casing; a landslide can shear the casing; weak casing may fail; well head equipment may break away; and steam may escape a long the outside of a casing if it is not adequately cemented. Recent technological advances have greatly reduced, but not eliminated, blowout risk.

The physical force of the blowout may itself destroy vegetation on adjacent land and strew debris around the landscape, and also cause sump failure with its own impacts, described above. A blowout will also be accompanied by an uncontrolled release of hydrothermal fluid. If fluid containing salts, heavy metals and other toxins enters the surface drainage system, it may infiltrate the groundwater body in dry stream beds or by percolation in upland soil; or it may travel as a hot chemical-laden slug of water through aquatic habitats. This could result in damage to those habitats by eliminating many organisms, with potential long-term consequences (USFWS, 1976); the extent of harm would, of course, depend on the temperature and constituents of the released fluid. The duration of the release depends on many factors, such as depth of the blowout locus.

Flow reductions at hot springs. Flows at surface hot springs could be reduced by lowering reservoir pressure; plants and aquatic organisms unique to the springs could be 10st, and the value of springs developed for recreational 
use could decrease markedly. (Such impacts are far more probable in the long-term FIELD DEVELOPMENT AND PRODUCTION phase, however, and are considered in more detail in that section).

Wellbore migration. The wellbore provides a path from the hydrothermal reservoir to aquifers that may overlie it. As a rule, a surface casing is required by law to protect any potable groundwater from contamination (Fig. 6). The casing is cemented to the wellbore surface and must extend below the lowest aquifer with potable water. Yet contamination may still occur by migration of fluid through the cement-formation interstice; through the casing-cement interstice; through a hole in the casing and a gap or break in the cement; etc. Adequate cementing has proven to be especially difficult in hydrothermal wells because the temperature tends to cause premature hardening; hardening can be retarded with chemicals, but at the risk of dilution of the cement by natural water convection in the formation (Kunze et a1., 1979). Moreover, casings in hydrothermal wells are made even more vulnerable by the fact that hydrothermal resources tend to coincide with areas of seismic activity.

Solid/liquid waste. Cuttings, drilling fluids, and any hydrothermal fluid produced in tests are ultimately deposited in the sump. Due to the toxicity of some mud and hydrothermal fluid components, the sump must be inpervious, lined with clay, plastic, or cement. If, upon completion of drilling and testing, the wastes accumulated in the sump are nontoxic, they may be evaporated and buried; toxic waste, however, must be transported to a licensed disposal site. The volume of solid waste produced in drilling hydrothermal wells is estimated as $20-40 \mathrm{~m}^{3}$ per $100 \mathrm{~m}$ of depth (Morris and Layton, 1980).

The contents of a sump could be released to the enviroment if the berm around it fails; if the sump overflows, e.g. due to heavy rains or to the unexpected discharge of hydrothermal fluid to the sump; or if the sump liner leaks. Some muds and hydrothermal fluids contain toxic substances which, if spread on the landscape, could harm plants and animals and, if transported by direct flow or by rain to surface water, aquatic organisms as well. The substances could also leach into potable groundwater in areas of permeable soils. Of course, animals could ingest the fluid in the sump if it is not fenced. 


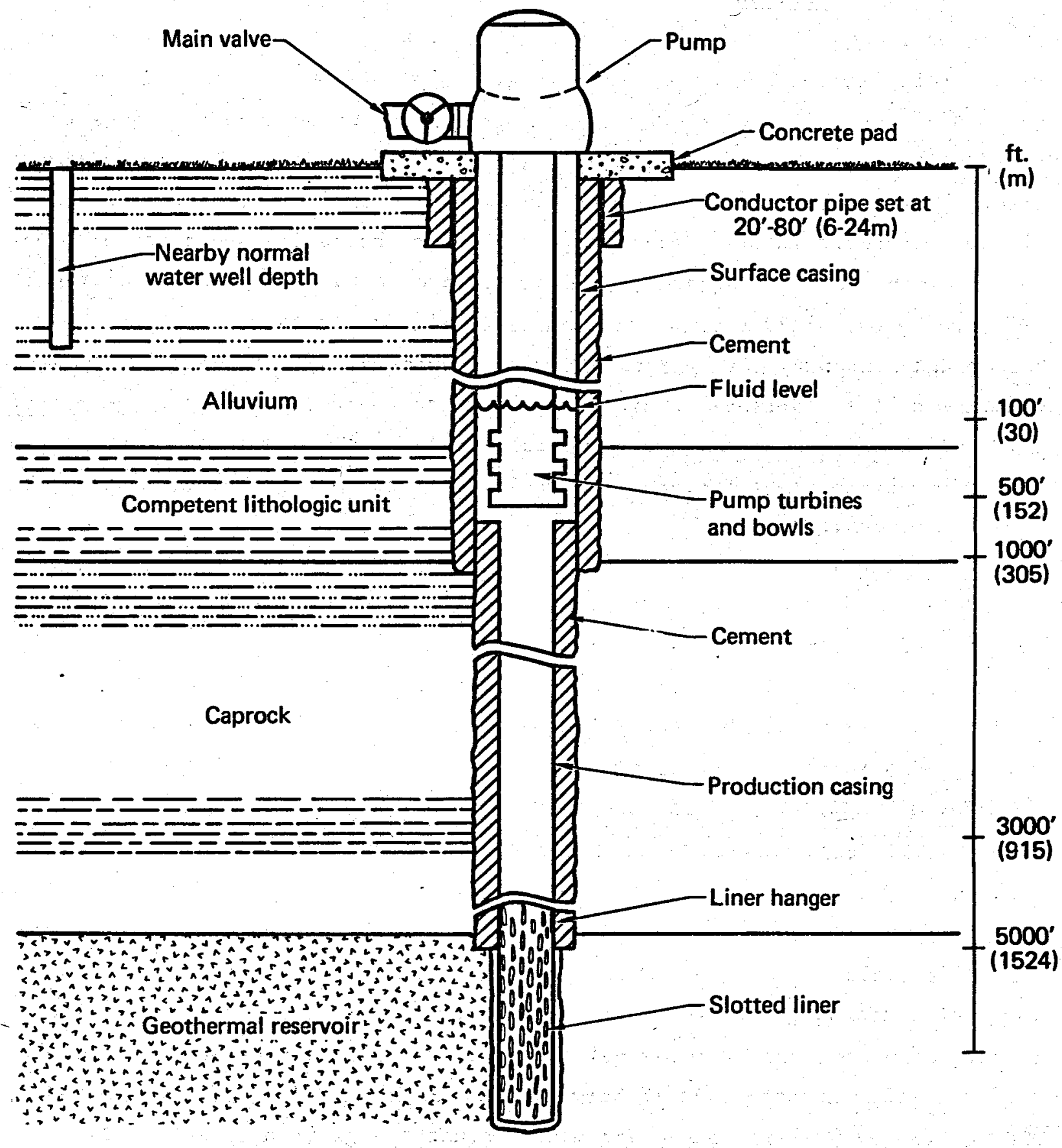

Figure 6. Cross-section of a typical hydrothermal well (not to scale) (Kunze et a1., 1979). 
Noise. While air drilling, such as is used at The Geysers vapor-dominated resource, can generate noise levels up to $120 \mathrm{dBA}$, mud drilling is considerably quieter, around 75-80 dBA (USEPA, 1977). Mud drilling, however, has a number of advantages compared to air drilling, namely: better lubrication and temperature control, longer equipment life, and safer conditions for workers (Kunze et a1., 1979). However, muds are not stable above $121^{\circ} \mathrm{C}$, and will bake and seal off production zones; for this reason the driller must change from mud to water or air when the production zone is encountered (Prestwich, 1980). Air drilling must be used in nonporous rock formations, where mud could clog the steam- or fluid-bearing fractures, but given its disadvantages will probably be 1 imited to those instances.

Drilling occurs $24 \mathrm{hr} / \mathrm{d}$ for $40-60 \mathrm{~d}$ per well. The potential impacts of mud drilling are similar to those for equipment noise described under GENERAL CONSTRUCTION, except that while the noise is not as loud (a sound decreased by $10 \mathrm{~dB}$ is perceived as only half as loud), unlike construction it is not limited to daytime, and thus may be more objectionable to humans, nearby residents in particular.

Air drilling is another story. With no muffling, the noise produced can hit $120 \mathrm{dBA}$, the pain threshold for humans, at $8 \mathrm{~m}$. The noise can be reduced to 85-95 dBA, however, by directing the blow line (the main source of noise) into an air chamber (USEPA, 1977). At this level, the noise impacts are comparable to those of GENERAL CONSTRUCTION.

Air emissions. The air emissions from the diesel generators are the same as those described in GENERAL CONSTRUCTION, and are similarly insignificant.

\section{We11 testing}

Once the well is completed, its productive potential must be evaluated. Fluid from the well will flow or be pumped into the waste sumps, while analyses are conducted of well head pressure, enthalpy, mass flow, fluid composition, ionic concentrations, etc. Volatization of the gaseous components of the fluid will occur during its evaporation in the sump, but given the limited scale of such tests the impact should be insignificant; workers, however, may have to be protected from localized concentrations in some instances. 
Release of hydrothermal fluid. Given the large volume of fluid that can be produced in a test (up to $32,400 \mathrm{~m}^{3}$, at a flow rate of $7.5 \mathrm{~m}^{3} / \mathrm{min}$ over a 72-hr test), an accidental release could seriously affect land and water downslope from the wellpad. The impacts would be the same as those described for well blowouts under Deep well drilling, above.

Subsidence and induced earthquakes. The withdrawal of fluid. from a liquid-dominated reservoir has the demonstrated potential to cause land subsidence. On the other hand, while reinjection of spent fluid can mitigate subsidence, it has the potential to induce earthquakes under certain conditions. (Both conditions are far more probable in the long-term FIELD DEVELOPMENT AND PRODUCTION phase, however, and are considered in more detail in that section below.)

\section{Wel1 abandonment}

If the well is successful, it will be shut down temporarily, to be reopened later for production. If it is unsuccessful, a few more experiments may be performed, then it will be filled with cement, and the site restored and abandoned.

\section{FIELD DEVELOPMENT AND PRODUCTION}

The size of the production "field" depends both on the characteristics of the resource and on user demand. In many instances, for example a group of houses or a greenhouse complex, one or two wells may suffice. On the other hand, a large district heat system may require a well field as large or larger than those required for power generation plants. For example, the Reykjavik municipal system, serving about 110,000 people, uses $3.8 \times 10^{7} \mathrm{~m}^{3}$ of fluid per year (Zoega, 1974). At an average flow rate of $30 \mathrm{l} / \mathrm{s}, 40$ wel1s would be required to produce this volume. (In fact, deep wells in Iceland produce up to $60 \mathrm{l} / \mathrm{s}$, but such yields are exceptional, limited to extensively. fractured volcanic areas, and not typical of yields to be expected in the U.S.; in general a $30 \mathrm{l} / \mathrm{s}$ deep well is considered a good producer. In shallower wells, however, yields of $60-125 \mathrm{l} / \mathrm{s}$ could reasonably be expected, based on yield figures from irrigation wells (Kunze et al., 1979).) 


\section{Field development}

If more wells are required than those drilled in the POST-LEASE EXPLORATION phase, the same procedures for road, pad, and sump construction and well drilling are repeated, with the same potential impacts as described in POST-LEASE EXPLORATION and GENERAL CONSTRUCTION, albeit of a greater magnitude. The total acreage required for a given output of fluid, and also the percentage of land disturbed, is expected to vary so widely that useful generalizations are hard to make; and, of course, our experience to date with liquid-dominated resources in the U.S. is very 1 imited (i.e. Klamath Falls, OR and Boise, ID; the only large-scale hydrothermal field developed so far in the U.S. is The Geysers field which, as a vapor-dominated resource developed for power generation, is hardly a reliable model for 1 iquid-dominated resources developed for direct use.) This phase does, however, require fluid lines and reinjection wells as well as production wells, and thus landscape disturbance must increase somewhat over the previous phase even if no more of the latter a re required.

Dumping the spent fluid into surface water is restricted to instances when volume and temperature are low and the fluid is of exceptional quality (or the fluid can be treated economically). The other surface disposal alternative, evaporation ponds, is feasible only when usable groundwater is i solated from leachate and, due to the volume of fluid involved even at a moderate flow rate, only in areas with extremely high rates of evaporation (Kunze et al., 1979). Moreover, not replacing the fluid withdrawn from the reservoir may shorten its productive life, alter its hydrology, and induce land subsidence (Sanya1, 1978). For all the above reasons, we expect most new direct-use hydrothermal development in the U.S. to include reinjection to the producing formation. The number of reinjection wells ranges from $0.5-1$ per production well.

Land disturbance can be kept to a minimum by slant drilling, whereby up to ten wells can be completed from a single $1.5-2.5$ ha pad ten conventional wells, by contrast, would require pads of up to 0.8 ha each, and they would have to be connected by roads and fluid lines, resulting in even more disturbance (Kercher and Layton, 1980): 


\section{Production}

Continuous withdrawal of large volumes of fluid over a long period can induce both hydrological changes in the reservoir itself and subsidence of the overlying land surface.

Land subsidence. Withdrawal of large volumes of fluid from a liquid-dominated reservoir can result in subsurface compaction as pressure drops; this compaction can result in turn in subsidence of the overburden. Compaction, and thus subsidence, can be mitigated by reinjecting spent fluid into the reservoir. But even when total reinjection is practiced some compaction can occur, because the fluid is injected at some distance from the production wells, to avoid mixing with produced fluid, and thus pressure drops near production wells are only partly mitigated. The response of overburden to compaction in a reservoir is quite variable and not easily predictable, but in general the thicker the overburden the lower the surface response (Layton and (row, 1980).

Significant land subsidence can alter surface drainage, and in extreme cases could result in bogs or ponds, particularly when surface soil is low in permeability. However, subsidence is a significant problem only in developed areas where changes in the land surface can damage roads and foundations, and play havoc with gravity-flow systems such as urban sewers or, as is feared in California's Imperial Valley, irrigation channels (Layton and Crow, 1980).

Induced earthquakes. The potential for induced earthquakes is usually dealt with in the context of increased reservoir pressure due to reinjection. But Marks et al. (1978) have linked increased activity (at Richter 2.0 and below) at The Geysers dry steam field to pressure drop and, possibly, cooling of the reservoir. The hydrothermal system at The Geysers, consisting of fractures in impermeable rock, is very different from the water-dominated, sedimentary reservoirs suitable for direct use, however, and whether or not a similar phenomenon might occur in the latter is entirely speculative. Geohydrologic impacts. The long-term extraction of hot fluids from hydrothermal reservoirs could affect hot springs, which are associated with many of the identified hydrothermal reservoirs in the U.S. For the reservoirs that do have hot springs, there is a risk that the long term extraction of fluids for direct use applications could cause a reduction, or even the cessation, of surface thermal discharges. Depending on the nature of the springs, changes in discharge could have several second-order 
consequences. If a hot spring, for example, is used by a health resort or spa, then a flow reduction would have an economic impact on the resort. Sometimes hot springs have spiritual value to Native Americans, and thus even the possibility that special one would cease flowing could be important. Hot springs can discharge waters that contain substances that are toxic to fish (e.g., ammonia and hydrogen sulfide), and in such instances, reductions in discharges would have a beneficial effect on aquatic ecosystems; on the other hand, in at least one case thermal waters without elevated levels of harmful substances have naturally mixed with surface waters, and the increase in temperature has resulted in enhanced fish reproduction (Sorey, 1976). Unique plant species may exist in the immediate vicinity of a spring, dependent on the thermal and chemical conditions created by the fluid discharge; they would be lost if the spring flow ceased.

Another area of concern is the potential impact on surface water rights. In the western U.S. most of the surface waters are developed by prior appropriation: that is, the first water user in time establishes the senior water right. As a consequence, the lowering of a stream's flow, because of reduced discharges from a spring, could affect the water right of senior appropriators. While the potential impacts described above underscore the importance of predicting the possible effects on springs prior to development, in practice it will often be difficult to accurately predict pressure changes in a reservoir and related reductions in spring discharge. Present analytical models used for aquifer/reservoir evaluation are based on assumptions (e.g.), isotropic, homogeneous material) that may not apply to the actual physical system under analysis. This is especially true for aquifers that are heavily fractured, which is frequently the case with hydrothermal systems. When it is difficult to predict impacts of pumping, greater reliance must be placed on monitoring reservoir pressure changes and spring discharges during production.

\section{Fluid lines}

Pipelines are required to collect fluid from the production wells; to transport it to the end use (s); and, if reinjection is practiced, to return the spent fluid to the reinjection wells.

Landscape disturbance. Pipelines may be constructed above or below $g$ rade, with the potential impacts described under GENERAL CONSTRUCTION. If they are above grade, and in an area prone to wildfires, vegetation within 
about $3 \mathrm{~m}$ of the lines on both sides is removed to create a firebreak. The low vegetation is maintained by cutting, use of herbicides, or both; unless used with care, herbicides can cause death or reduced reproduction in nontarget organisms. The firebreaks may be too wide for small animals to cross, since the absence of cover exposes them to predators; the isolated parcels of land they create, on the other hand, may not be large enough to be viable as habitats. The above-grade lines themselves, moreover, may block the movement of larger animals.

\section{Reinjection}

Hydrothermal fluids are brought to the surface, heat is extracted, and then the fluids, now cooler, must be disposed of. Except in cases where the fluid is pure enough for surface disposal, it must be reinjected, as a rule to the producing formation.

Wellbore migration. While reinjection wells return fluids containing toxic or undesirable minerals to the formation of origin, they pose the same risk of contaminating overlying aquifers as do production wells, described in POST-LEASE EXPLORATION.

Induced earthquakes. There is some concern that injection of spent fluids into reservoirs may enhance seismic activity. The concern originates from two incidents in Colorado, at Rangely and near Denver, linking high-pressure subsurface injection with seismic activity. At Rangely, the existence of a threshold formation pressure was demonstrated: it was shown that by raising injection pressure above the threshold, earthquakes could be induced, evidently caused by a decrease in the physical strength of the rock (Raleigh et al., 1975). The mechanisms for the decrease in rock strength include forcible lubrication of fracture planes and dilatation, or an increase in pore pressure to the point of rock fracture (Layton and Crow, 1980).

The Colorado incidents are rare, however, and in contrast to wide experience with fluid injection used by the oil and gas industry to increase reservoir productivity. No documented evidence of induced seismicity has been found with regard to this practice, nor with other waste water disposal techniques using injection. Probably a major factor for the absence of significant induced activity is the control of injection pressures by state regulations. Although the various regulations are stated in different ways, the effect is to limit downhole injection pressures below $0.8 \mathrm{psi} / \mathrm{ft}$ depth, to 
avoid reservoir rock fracture (Layton and Crow, 1980). Monitoring of pilot-scale reinjection in the Imperial Valley has disclosed no induced seismicity, despite its being traversed by a number of active faults.

\section{ABANDONMENT AND RESTORATION}

At some point, due to change in the relative value of hydrothermal energy; depletion of the resource due either to withdrawals in excess of recharge or a decrease in the recharge rate (due, for example, to urban development in the resource area); or changes in the fluid composition, hydrothermal fields are expected to be abandoned. All surface improvements will be removed and the wells shut in, leaving a disturbed landscape. The dismantling and removal of improvements entails the use of the same type of heavy equipment that brought it in the first place, with potential impacts as described under GENERAL CONSTRUCTION.

Regrading and replanting of the raw, disturbed land that remains is usually required by the state or locality. While the land would begin to revert to its pre-development condition in the absence of such restoration, in some places the successional stages involved can take 50-100 yr; during the interim, damage (e.g. soil erosion, changes in faunal populations) can occur that permanently alter the ecosystem.

vI. SUMMARY OF IMPACTS AND MITIGATION : EXPLORATION, FIELD DEVELOPMENT, PRODUCTION AND REINJECTION

Table 7 lists the potential impacts described in the previous section, and also how they may be avoided or mitigated.

\section{IANDSCAPE DISTURBANCE}

Habitat $108 s$ varies with the intensity of development and with terrain; rugged terrain requires far more land disturbance to create flat pads and roads. If, for example, field was relatively flat, and developed at a density of 1 wel1/8 ha (Basse, 1976), land disturbance would be on the order of 10-20\%. Once the field is completed, however, only the roads, fluid ine firebreaks (if above grade), and service areas around each wellhead must remain clear; the balance of disturbed land may be replanted. In our example this balance, up to half of the total disturbed, would consist of pads, sumps, 
parking lots, storage yards, etc.. In areas of more rugged terrain, the raw slopes created by cutting and filling must also be replanted. The land may either be restored to its pre-development condition, or its habitat value may be improved by altering the plant mosaic (e.g. to create more ecotones) or introducing new varieties. Revegetation is no panacea, however: in areas, such as the desert, where recoverability of vegetation is"low it can take decades for pre-development conditions to return, hence the importance of minimizing land disturbance to begin with.

A certain amount of soil erosion is unavoidable, if only due to the action of wind on cleared soil. However, it is a problem primarily in areas of rugged terrain and erodible soils, such as The Geysers and the Cascade Range. If uncontrolled, soil erosion results in deposition of sediment and soil nutrients in streams, with adverse consequences for aquatic biota; culverting and berming around cleared areas, however, can intercept this flow and hold or divert it. While soil erosion itself can be reduced by limiting the area disturbed, avoiding slopes $>30 \%$, replanting as soon as the field is complete, and timing construction (the most vulnerable phase) to avoid the rainy season, erosion-prone land will still experience some increase in topsoil loss. The resultant exposure of subsurface soil may lead to permanent changes in nutrient cycles and vegetation mix.

Alteration of natural contours can change drainage and, in mountainous areas with unstable rock formations, induce landslides. Both can, in turn, encourage soil erosion; drainage changes by increasing runoff velocity and causing gullying, landslides by exposing subsurface soils. The downslope impacts of changed drainage can be mitigated by culverting and berming, but the upslope landscape can only be protected by minimizing disturbance. Landslide-prone sites can be fairly reliably disclosed by geologic investigation, and avoided.

The impact of hydrothermal development on the visual quality of a landscape is mainly a function of terrain, since damage on a slope is visible over a much larger area, and of the area's recreational and/or residential value. Again, limiting the amount of land disturbed and replanting it properly can reduce, but not eliminate, the damage. Particularly in mountainous, forested areas, burial of fluid lines can make a dramatic improvement in visual quality, since the cleared firebreaks required for surface lines stand out against the dark natural background. 
Table 7. Potential impacts, mitigation measures, and research requirements for hydrothermal direct use.

Potential Impacts

a . Land disturbance associated with exploration and road, pad, sump, and fluid line construction can, in larger-scale projects, result in habitat loss; soil erosion; damage to visual quality and historical artifacts; and, in hilly terrain historical artifacts; and, in hilly

b. Noise and human presence associated with construction and well drilling can disturb both humans and wildlife in the vicinity, and disrupt wildlife mating and nesting cycles.

c. Water contamination can result from well blowouts; pipe rupture; migration of hydrotherma fluid to an overlying aquifer; leaching of sump waste; and overflow or failure of the sump walls. It can also result from the discharge to surface (or potable ground) water of spent fluid below the potable ground) water of spent fuld belor

d. Land subsidence can result from large fluid withdrawals from hydrothermal reservoirs, damaging buildings and infrastructure in developed areas.

e. Surface flow reduction may also result from f luid withdrawals, which can in turn lead to thermal and chemical changes in surface water: loss of balneological value; and 1085 of cultural value to Native Americans.

f. Induced seismicity can occur when reinjection exceeds the threshold point of formation rock; smaller changes in pore pressure may al so have
the potential to "trigger" earthquakes in faulted

Research Requirements

Minimizing travel off roads/trails

Utilizing multiwell pads/sumps to reduce

reduce disturbed area

Siting to avoid critical habitats (e.g. riparian

areas, wetlands, mating/nesting areas)

Revegetating cleared land once field is completed Avoiding critical viewsheds

Burial of fluid lines

Timing to avoid rainy season

limiting cut slopes to $<30 \%$

Avoiding

Berming around pads, culverting along roads

and at base of cut slopes to intercept runof

Avoiding known unstable formation

Avoiding known historical sites

Muffling if sensitive human or animal

receptors nearby

Timing to avoid sensitive wildife cycles

siting to avoid critical habitats

Using "blowout preventer" devices

at wellheads
Avoiding weak or unstable soils

to prevent well damage, sump failure

Berming around pads and sumps to

intercept spills

Treating fluid of below-ambient

quality prior. to surface discharge

Reinjecting spent fluid

Reinjecting spent fluid

Maintaining injection pressure
below generally safe (sub-threshold)

level
Observe the responses of various

wildife species to changes in habitat

characteristic of direct-use development.
Observe the responses of various wildlife species to types and levels of noise characteristic of direct-use development.

Perform a comprehensive assessment of the cost and performance of wastewater treatment methods

Monitor rates of subsidence in various geologic media overlying producing reservoirs

Investigate adequacy and reliability of reinjection technology for sub $-150^{\circ} \mathrm{C}$ fluids

Monitor changes in surface flows at waterbodies fed by producing reservoirs

Monitor effects of injection in seismicially active areas in 

Known historical or archaeological sites can also be avoided, but unknown, subsurface resources may be unearthed during construction. Pre-development investigations may be conducted at sites with a high probability of value, particularly around surface hot springs. When construction does disclose artifacts of potential value, work should cease until an archaeologist can come to the site and assess their significance. Given the low percentage of land disturbance in a hydrothermal field, in most instances the developer should be able to replan the field to avoid the archaeological site.

Lastly, the roads built to service the hydrothermal development may, in certain instances, provide public vehicular access to previously remote areas, and thus increase both wildife disturbance and the risk of wildfire.

\section{NOISE AND HUMAN ACTIVITY}

While construction and drilling produce noibe which at close range is annoying (75-90 dBA) and, in the case of unmuffled air drilling, even painful ( $120 \mathrm{dBA})$ to humans, it is of relatively brief duration $(<3 \mathrm{mo})$ and, if nearby sensitive receptors require, can be reduced by devices and/or enclosures. The impact of noise and human activity on wildlife is unknown, but animals who rely on sound for hunting, mating, or defense could suffer audial damage, and critical activities such as mating and nesting could be disrupted.

\section{WATER CONTAMINATION}

In direct-use development, contamination of ground and/or surface water can result from a variety of mishaps: vel1 blowouts; pipe rupture; migration of hydrothermal fluid to an overlying aquifer, due to casing failure; leaching of sump wastes, due to inadequate lining, and overflow or failure of the sump wall.

Sump failure or overflow and blowouts can cause large volumes of hydrothermal fluid, and in the former case drilling muds, to flow over the downslope landscape. Both can contain a variety of toxic substances. If the released fluid reaches surface water, many aquatic biota could be killed, and the health of animals and humans who drink the contaminated water impaired. On the other hand, even if the flow itself does not reach surface water, rain could transport it there and/or cause it to percolate to groundwater. The use 
of blowout prevention devices, and the avoidance of weak or slide-prone formations can reduce the risk of blowouts to a very low level; similarly, sump failure can be largely prevented by avoidance of weak or slide-prone formations and natural drainage courses and adequate compaction of sump walls. Berms can also be built around pads and sumps to contain the released fluid, but a blowout of any duration would soon exceed the moat capacity. Sump fluids can leach to groundwater if an impervious lining is not properly installed. Prevention is largely a matter of placing the lining with reasonable care and, if the fluids are toxic, removing them to a toxic waste dump once drilling and well testing are complete. Contamination due to wellbore migration, under normal circumstances, is prevented by casing the well to a depth below potable groundwater. However, migration can occur if the casing or cement cracks, due to thermal expansion or formation movement, or if the cement does not bond adequately to the wellbore. Avoidance of weak or slide-prone formations can reduce the risk of migration, but cementing has proven to be problematic in hydrothermal wells due to the temperatures involved, and some risk of failure remains.

All of the above mishaps can be induced by earthquakes or landslide. While soils and rock formations most prone to failure can be avoided, because of the unpredictability of seismic activity, and the fact that hydrothermal resources tend to coincide with seismic faults, some risk of water contamination due to the above mishaps is unavoidable.

\section{LAND SUBSIDENCE}

The loss of pressure that results from fluid withdrawal in liquid-dominated reservoirs can cause subsidence of the overlying surface. Subsidence can be mitigated by total reinjection of spent fluid to the reservoir, but because the spent fluid is injected some distance from the production well, a certain amount of pressure loss around the latter will still occur. Whether or not it causes measurable subsidence depends on the geologic characteristics of the site in question; however, the pressure loss itself is unavoidable unless the reinjected fluid is supplemented to compensate for the lower temperature. While subsidence can alter surface drainage, and thus could produce ecological changes, in natural areas, it is mainly a problem in developed areas, where even a minor amount can seriously damage buildings and infrastructure. 
SURFACE FLOW REDUCTION

Loss of reservoir pressure can also result in reduction of flows in surface hot springs. Potential impacts include loss of unique plant species in the spring vicinity; changes in the thermal and chemical properties of water bodies fed by the spring; loss of balneological value; and/or damage to a feature of cultural/religious importance to Native Americans. Again, most of the pressure $10 s s$ can be avoided by reinjection.

\section{INDUCED SEISMICITY}

If spent fluid is reinjected at pressures high enough to cause reservoir rock to threshold, there is a danger that earthquakes could be induced. However, while the fracture pressure of a formation can not be predicted, limiting injection pressure to a generally safe level $(0.8 \mathrm{psi} / \mathrm{ft}$ of depth in most state regulations) can minimize the risk (Layton and Crow, 1980). Moreover, while hydrothermal resource areas experience more frequent microtremors due to natural causes than do adjacent areas, major earthquakes are rare (USEPA, 1977). The microtremors could conceivably relieve tectonic stress; if so, the risk of inducing a major quake in a hydrothermal area may be lower than in other areas.

\section{vII. POTENTIAL ENVIRONMENTAL IMPACTS:}

\section{UTILIZATION}

Under normal operation, a closed system in which all produced fluids are reinjected should have almost no environmental impact. With highertemperature fluids, an accidental rupture in the system could cause not only burns but also a release of gases contained in the fluid, most notably hydrogen sulfide $\left(\mathrm{H}_{2} \mathrm{~S}\right)$, ammonia $\left(\mathrm{NH}_{3}\right)$ and mercury $(\mathrm{Hg})$, that are hazardous at sufficient concentrations and durations of exposure.

While closed systems are expected to be the norm, certain industria 1 operations that require large quantities of process steam or hot water may wish to utilize the hydrothermal fluid directly, rather than incur the extra cost of heat exchangers. Such operations would encounter the same problems with released gases as described above, except on a sustained basis. $\mathrm{H}_{2} \mathrm{~S}$ is the substance of primary concern, since even at levels far below those hazardous to health, it can produce a severe odor nuisance: $50 \%$ of the 
population can detect its odor at concentrations between 0.003 and 0.009 ppmv (Anspaugh and Leitner, 1980). While this gas is not contained in all thermal waters, it is frequently associated with higher-temperature fluids. A large industrial operation, flashing large volumes of $>100^{\circ} \mathrm{C}$ fluid to produce steam, could emit enough $\mathrm{H}_{2} \mathrm{~S}$ to cause aversive odors not only within the plant but also in the surrounding vicinity. Again, depending on the chemical makeup of the fluid, other substances besides $\mathrm{H}_{2} \mathrm{~S}$ could also pose health or odor impacts.

Another consideration in such "open" systems is fluid disposal. In instances where the fluid is $>100^{\circ} \mathrm{C}$, and is flashed to steam, only a portion can be recovered for reinjection. Reservoir pressure will decline at a much faster rate than would otherwise be the case, thus increasing the risk of land subsidence. Makeup water could be used, but this practice is both costly and, of particular importance in the arid regions of the western U.S., diverts water from other uses.

The general potential impacts of fluid lines are described in the previous two sections. However, when the end-users are located of $f$ the production field, the lines that transport the fluid from the field to the end-users and back are far more likely to be underground and routed along established rights-of-way, in which case their environmental impact. should be negligible.

The energy system utilized by a given development is only one source of the development's environmental impact, of course. We do expect that many direct-use applications in the very near future will be retrofits of existing systems fueled by natural gas, coel, or oil. Since in those instances the energy system is the only thing that is changed, their utilization-related impacts should be limited to the temporary disturbances and increases in local income associated with installation of the system, plus whatever the end-users save as a result of the conversion. A new facility, however, poses in addition some impacts that are longterm in nature, associated both with the facility itself and with the permanent jobs it creates.

Development that may be induced by hydrothermal energy ranges in type and size from a single house to an industrial complex. Given as well the variety of environments in which hydrothermal resources occur, the potential secondary impacts of such development (e.g. land use conflicts; worker inmigration and 
its cultural and, fiscal effects; increased loads on infrastructural systems; increased tax yields) can only be dealt with meaningfully on a project- or area-specific basis. One point, however, is worth mentioning:

Because hydrothermal resource areas, for the most part, are sparsely developed, relatively homogeneous in culture, and have experienced slow historical rates of change, it does not take much of an impact, in absolute terms, to cause significant perturbations in the lifestyles of their residents. Gilmore (1976), in his article on "energy boomtowns," notes that a $15 \%$ growth rate [over a short time period] leads to institutional breakdowns in the labor and housing markets and the fiscal system. The frequently heard claim that the socioeconomic impacts of direct-use development are negligible must always be evaluated in this context.

\section{CONCLUSIONS}

The production of hydrothermal energy for direct use poses a wide range of potential environmental impacts. However, all are largely or entirely avoidable, by careful siting and timing; by established mitigation techniques (such as berming/culverting to reduce erosion and contain spills); by reinjecting spent fluid; and by adequately restoring the vacated field. In areas of special ecological or recreational value, disturbance of the landscape can be further reduced by utilizing multiwell drillpads and by burying the fluid lines.

The impacts of utilization of the energy produced depend on the type of application and on whether the system is "open" or "closed". Under normal operation, closed systems should have no environmental impact; however, "open" systems in which the hydrothermal fluid is flashed to steam can emit harmful gases (most notably $\mathrm{H}_{2} \mathrm{~S}$ ), and since only a portion of the fluid is available for reinjection, can also increase the risk of land subsidence. of course, direct-use development can have many application-specific environmental impacts that are unrelated to the energy system itself; for example, the jobs and land-use conflicts resulting from a greenhouse complex or a food processing facility. Direct-use applications are so numerous and diverse, however, such impacts can not be done justice in a generic report, except to note that the sparsely developed and relatively stable and homogeneous regions in which hydrothermal resources tend to be found are far more vulnerable to socioeconomic disruption than are more urbanized regions. 


\section{REFERENCES}

L. Anspaugh and P. Leitner, "Health and Safety Concerns", in An Assessment of Geotherma1 Development in the Imperial Valley, D. Layton Ed., U.S. Department of Energy, Washington, DC, DOE/EV-0092 Vol . 1 (July 1980).

B.B. Basse, "Thermal Energy Utility Systems", in Susanville Geothermal Energy Project: Workshop Proceedings/Final Technical Report, City of Susanville, CA (13 July 1976).

S. Bressler and W.M. Hanemann, Prospects for Geothermal Commercialization in the Lumber Industry, Earl Warren Legal Institute, University of California, Berkeley, CA (March 1980).

S. Bressler and W.M. Hanemann, Prospects for Geothermal Commercialization in the Potato and Onion Industry, Earl Warren Legal Institute, University of California, Berkeley, CA (March 1980).

S. Bressler and W.M. Hanemann, Prospects for Geothermal Commercialization in the Chemical Industry, Earl Warren Legal Institute, University of California, Berkeley, CA (March 1980).

S. Bressler and W.M. Hanemann, Prospects for Geothermal Commercilization in the Greenhouse Industry, Earl Warren Legal Institute, University of Californie, Berkeley, CA (March 1980).

C.A. Brook, R.H. Mariner, D.R. Mabey, J.R. Swanson, M. Guffanti, and L.J.P. Muffler, "Hydrothermal Convection Systems with Reservoir Temperatures $>90^{\circ} \mathrm{C} "$ ", in Assessment of Geothermal Resources of the United States: 1978, L.J.P. Muffler, Ed., U.S. Geological Survey, Arlington, VA, Circular 790. (1979).

V.V. Einarsson, "Geothermal Space Heating and Cooling", in Proceedings: Second United Nations Symposium on the Development and Use of Geothermal Resources, Vol. 3, San Francisco, CA (20-29 May 1975). 
J.S. Gilmore, "Boom Towns May Hinder Energy Resource Development," Science 191, pages 535-540 (1976).

J.G. Goodwin, Jr., Big Game Movement Near a $500 \mathrm{kV}$ Transmission Line in Northern Idaho, Bonneville Power Administration, Portland, OR (1975).

K. Haven, V. Berg, and Y. Ladson, Local Population Impacts of Geotherma 1 Energy Development in The Geysers-Calistoga KGRA Region, Lawrence Berkeley Laboratory, Berkeley, CA, LBL-10150 (June 1980).

J. Kercher and D. Layton, "Impacts on Agricultural Resources", in An Assessment of Geothermal Development in the Imperial Valley of California, D. Layton, Ed., U.S. Department of Energy, Washington, DC, DOE/EV-0092 Vo1. 1 (July 1980).

D. King, J.T. Nimmons, and W.M. Hanemann, The Role of Gas and Electric Utilities in Direct Applications of Geothermal Resources, Earl Warren Legal Institute, University of California, Berkeley, CA (March 1980).

J.J. Kunze, R.G. Bowen, K. Foit, D. Goldman, and E. Zais, "Reservoir Development and Management", in Direct Utilization of Geothermal Energy: a Technical handbook, D.N. Anderson and J.W. Lund, Eds., Geothermal Resources Council, Davis, CA, Special Report \$7 (1979).

D. Layton and N. Crow, "Subsidence and-Seismicity", in An Assessment of Geothermal Development in the Imperial Valley, D. Layton, Ed., U.S. Department of Energy, Washington, DC, DOE/EV-0092 Vol. 1 (July 1980).

P.J. Lienau, J. Austin, J. Balzhiser, R.G. Campbell, M. Conover, G.G. Culver, L. Donovan, L.A. Fisher, R.L. Miller, R.C. Neiss, and G. Reistad, "Utilization", in Direct Utilization of Geothermal Energy: A Technical Handbook, D.N. Anderson and J.W. Lund Eds., Geothermal Resources Council, Davis, CA, Special Report \#7 (1979).

P.J. Lienau, "Heat Pumps and Geothermal," Geoheat Utilization Center Quarterly Bulletin 5, pages 4-10 (1980). 
J.W. Lund, G.G. Culver, and L.S. Svanevik, "Utilization of Geothermal Energy at Klamath Falls," presented at the International Conference on Geothermal Energy for Industrial, Agricultural, and Commercial-Residential Uses, Oregon Institute of Technology, Rlamath Falls, OR (1-9 October 1974).

S.M. Mark6, R.S. Ludwin, K.B. Louie, and C.G. Bute, Seismic Monitoring at The Geysers Geothermal Field, California, U.S. Geological Survey, Menlo Park, CA, Open-File Report 78-798 (1978).

W. Morris and D. Layton, "Liquid and Solid Wastes, "in An Assessment of Geothermal Development in the Imperial Valley, D. Layton, Ed, U.S. Department of Energy, Washington, DC, DOE/EV-0092 Vol. 1 (July 1980).

National Research Council, Geothermal Resources and Technology in the United States, National Academy of Sciences, Washington, DC (1979).

J. Nielson, Ed., Draft Environmental Impact Report for Burmah Oil and Gas Company, Wildhorse Leasehold, Ecoview Environmental Consultants, Napa, CA (1975).

K. O'Banion and C. Hall, Geothermal Energy and the Land Resource: Conflicts and Constraints in The Geysers-Calistoga RGRA, Lawrence Livermore National Laboratory, Livermore, CA, UCRL-52970 (July 1980).

S. Prestwich, "Low Temperature Drilling Techniques for Direct Use Applications," in Commercial Uses of Geothermal Heat, Geothermal Resources Council, Davis, CA, Special Report \#9 (June 1980).

D.B. Raleigh, J.H. Healy, and J.D. Bredehoeft, "An Experiment in Earthquake Control at Rangely, Colorado," Science 191, pages 1230-1237 (1975).

G.M. Reistad, Analysis of Potential Nonelectric Applications of Geothermal Energy and their Place in the Economy, Lawrence Livermore National Laboratory, Livermore, CA, UCRL-51747 (February 1975). 
L. Rigdon, Defluoridation Study for Boise Geothermal Water, Lawrence Livermore National Laboratory, Livermore, CA, UCID-18646 (June 1980).

J.L. Sanyal, "Appendix B: Injection of Liquid Wastes," in Identification of Environmental Control Technologies for Geothermal Development in the Imperial Valley of California, D.F. Snoeberger and J.H. Hill, Lawrence Livermore National Laboratory, Livermore, CA, UCRL-52548 (1978).

Sorey, M. L. Potential Effects of Geothermal Development on Springs at the Hot Creek Fish Hatchery in Long Valley, Mono County, California, U.S. Geological Survey, Menlo Park, CA, Open-file Report 75-637 (1976).

R. Stobaugh and D. Yergin, Eds,, Energy Future, Random House, New York, NY (1979).

U.S. Environmental Protection Agency, Western Energy Resources and the Environment: Geotherma1 Energy, EPA-600/9-77-010 (May 1977).

U.S. Environmental Protection Agency, Pollution Control Guidance for Geotherma 1 Energy Development, EPA-600/7-78-101 (June 1978).

U.S. Fish and Wildlife Service, Geothermal Handbook, U.S. Department of the Interior, Washington, DC, NP-21172 (June 1976).

U.S. Geological Survey, National Atlas of the United States of America, U.S. Department of the Interior, Washington, DC (1970).

U.S. Geological Survey, Unpublished data, GEOTHERM Data Base, Menlo Park, CA (1980).

Woodward-Clyde Consultants, Impact Prediction Manual for Geothermal

Development, U.S. Department of the Interior, Washington, DC, FWS/OBS $-78 / 77$ (June 1978). 
J. Zoega, "The Reykjavik Municipal District Heating System," presented at the International Conference on Geothermal Energy for Industrial, Agricultural, and Commercia1-Residential Uses, Oregon Institute of Technology. Klamath Falls; OR (7-9 October 1974). 
Technical Information Department - Lawrence Livermore National Laboratory University of California - Livermore, California 94550

\section{First Class Mail}

